\title{
Closure Plan for the E-Area Low-Level Waste Facility
}

by

J. R. Cook

Westinghouse Savannah River Company

Savannah River Site

Aiken, South Carolina 29808

E. L. Wilhite

K. E. Young

Exploration Resources, Inc.

This paper was prepared in connection with work done under the above contract number with the U.S.

Department of Energy. By acceptance of this paper, the publisher and/or recipient acknowledges the U. S.

Government's right to retain a nonexclusive, royalty-free license in and to any copyright covering this paper, along with the right to reproduce and to authorize others to reproduce all or part of the copyrighted paper. 


\section{DISCLAIMER}

This report was prepared as an account of work sponsored by an agency of the United States Government. Neither the United States Government nor any agency thereof, nor any of their employees, makes any warranty, express or implied, or assumes any legal liability or responsibility for the accuracy, completeness, or usefulness of any information, apparatus, product or process disclosed, or represents that its use would not infringe privately owned rights. Reference herein to any specific commercial product, process or service by trade name, trademark, manufacturer, or otherwise does not necessarily constitute or imply its endorsement, recommendation, or favoring by the United States Government or any agency thereof. The views and opinions of authors expressed herein do not necessarily state or reflect those of the United States Government or any agency thereof.

This report has been reproduced directly from the best available copy.

Available for sale to the public, in paper, from: U.S. Department of Commerce, National Technical Information Service, 5285 Port Royal Road, Springfield, VA 22161,

phone: (800) 553-6847,

fax: (703) 605-6900

email: orders@ntis.fedworld.gov

online ordering: http://www.ntis.gov/ordering.htm

Available electronically at http://www,doe.gov/bridge

A vailable for a processing fee to U.S. Department of Energy and its contractors, in paper, from: U.S. Department of Energy, Office of Scientific and Technical Information, P.O. Box 62,

Oak Ridge, TN 37831-0062,

phone: (865)576-8401,

fax: (865)576-5728

email: reportsbadonis.osti.gov 


\section{DISCLAIMER}

Portions of this document may be illegible in electronic image products. Images are produced from the best available original document. 
KEY WORDS: Stewardship

Waste Management

Environmental Protection

\section{Closure Plan for the E-Area Low-Level Waste Facility}

James R. Cook ${ }^{\mathrm{a}}$

Elmer L. Wilhite ${ }^{a}$

Karen E. Young ${ }^{b}$

${ }^{a}$ Westinghouse Savannah River Company

${ }^{b}$ ExR

Rev. 1

October 12, 2000

Westinghouse Savannah River Company

Savannah River Site

Aiken, SC 29808

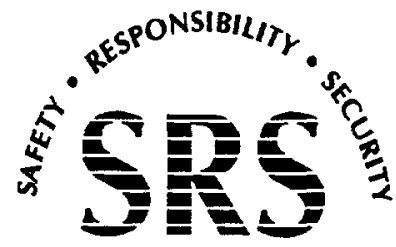




\section{RECEVED \\ NOV $O 92000$ \\ OSTI}

WSRC-RP-2000-00425

KEY WORDS: Stewardship

Waste Management

Environmental Protection

\section{Closure Plan for the E-Area Low-Level Waste Facility}

James R. Cook ${ }^{\mathrm{a}}$

Elmer L. Wilhite ${ }^{\mathrm{a}}$

Karen E. Young ${ }^{b}$

a Westinghouse Savannah River Company

${ }^{b}$ ExR

Rev. 1

September 15, 2000

Westinghouse Savannah River Company

Savannah River Site

Aiken, SC 29808

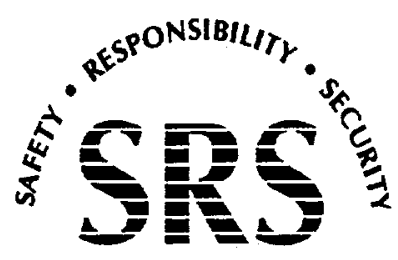




\section{Authors}

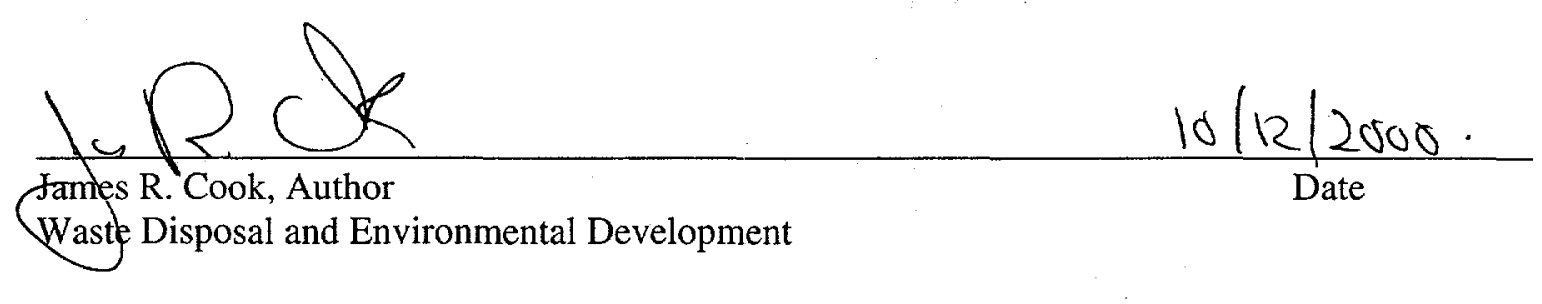

$\frac{\text { WEStereis for EL Wilhite }}{\text { Elmer L. Wilhite, Author }} \frac{10 / 12 / 2000}{\text { Waste Disposal and Environmental Development }}$

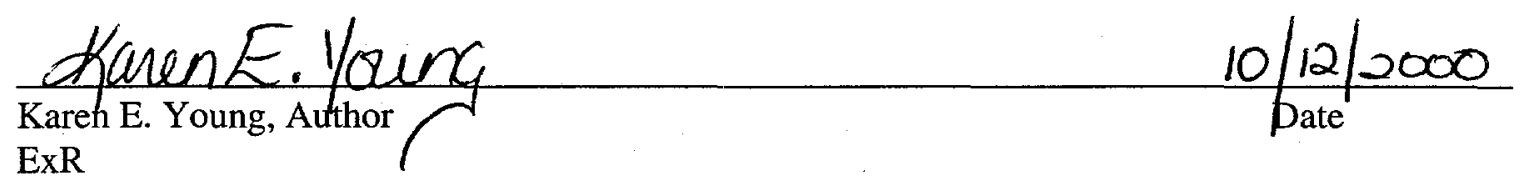

\section{Approvals/Review}

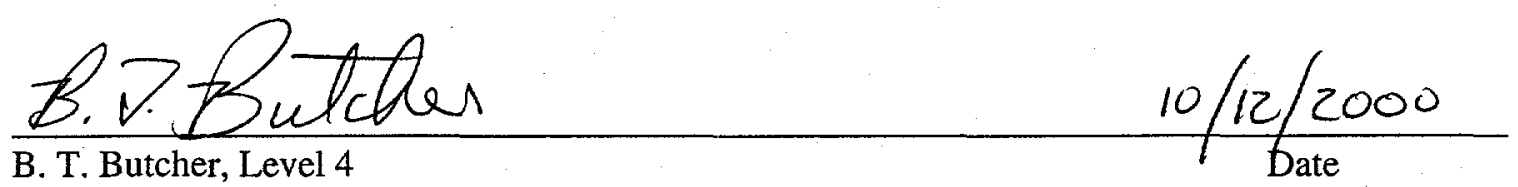

Waste Disposal and Environmental Development

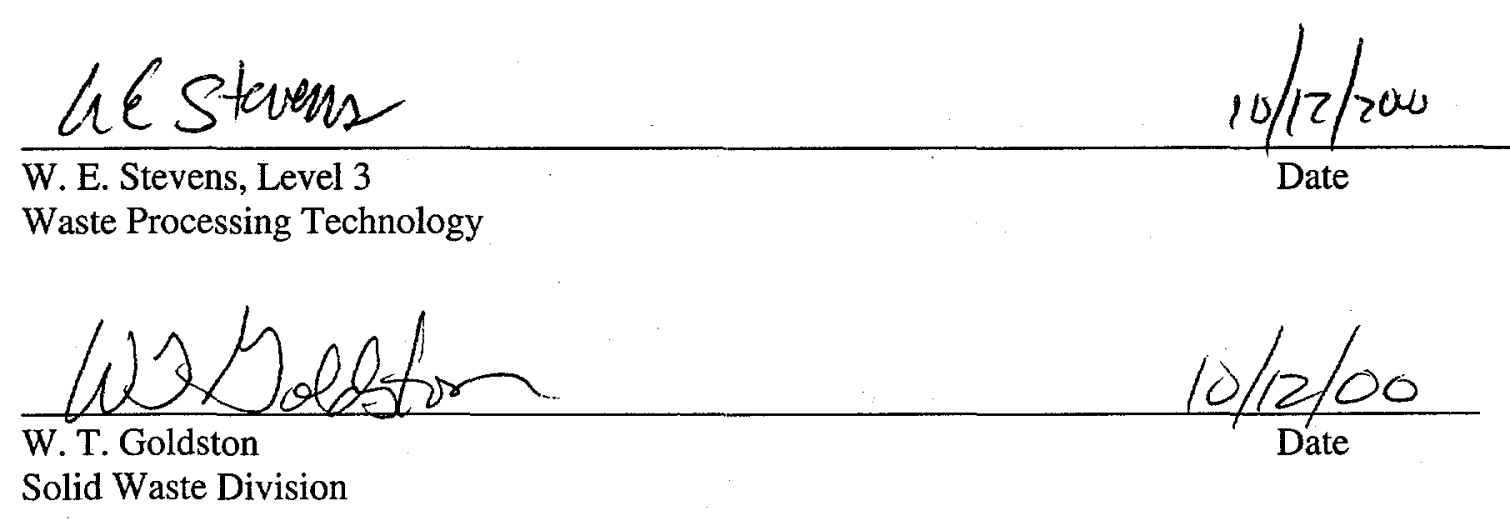




\section{CONTENTS}

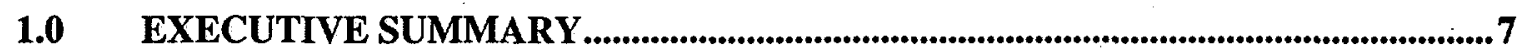

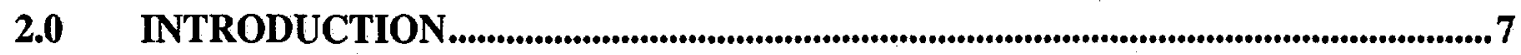

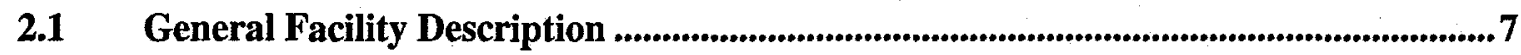

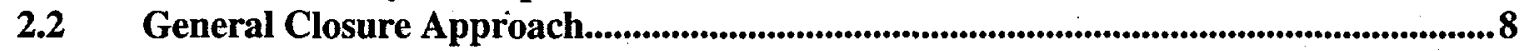

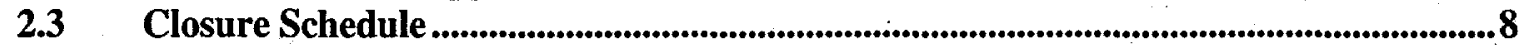

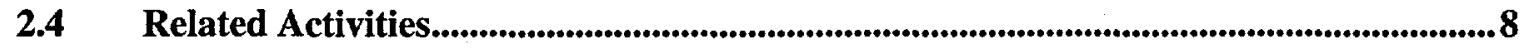

2.5 Summary of Key Assumptions.............................................................................................9

3.0 DISPOSAL FACILITY CHARACTERISTICS ...........................................................9

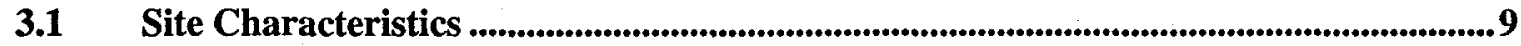

3.1.1 Geography and Demography .........................................................................................10

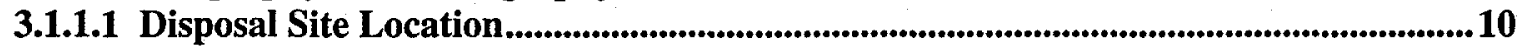

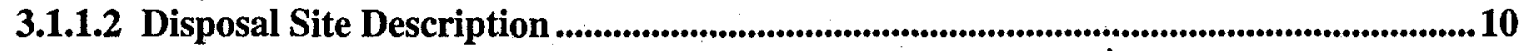

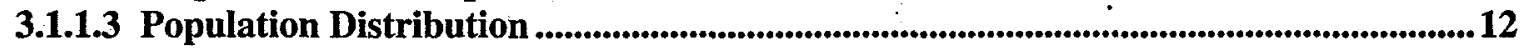

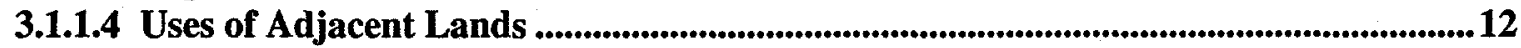

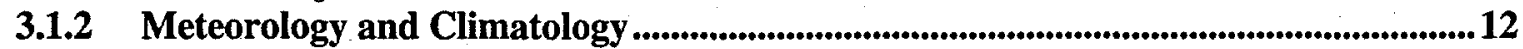

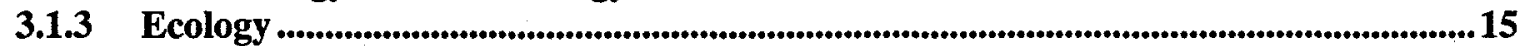

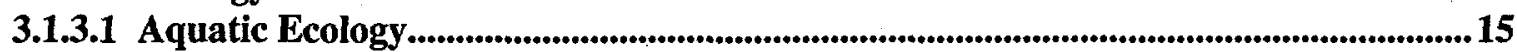

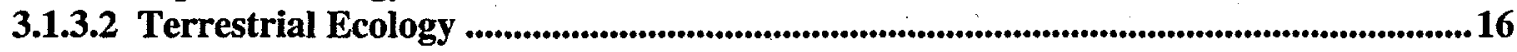

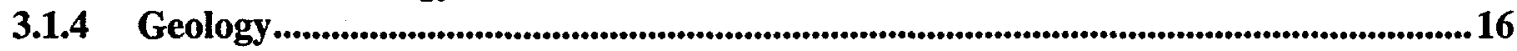

3.1.4.1 Regional and Site-Specific Geology/Topography ...................................................16

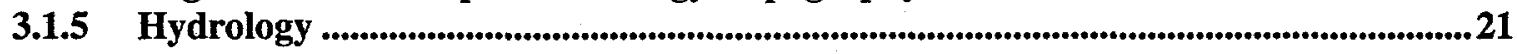

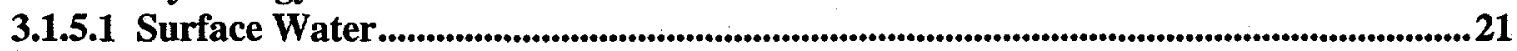

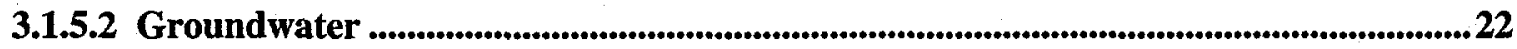

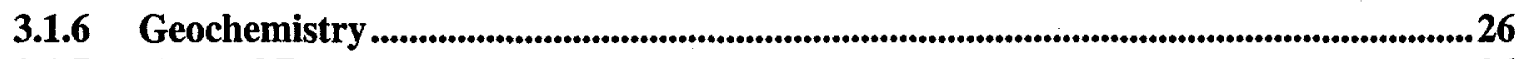

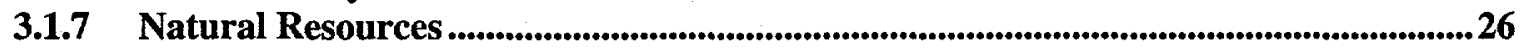

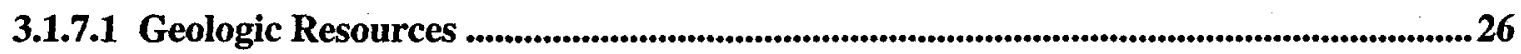

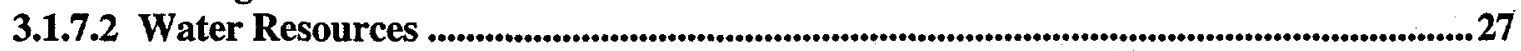

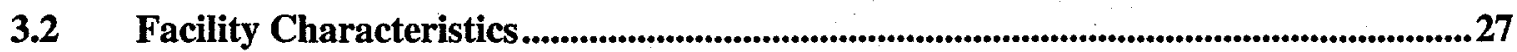

3.2.1 Water Infiltration and Disposal Unit Cover Integrity ...................................................27

3.2.1.1 Low-Activity Waste Vaults.................................................................................................27

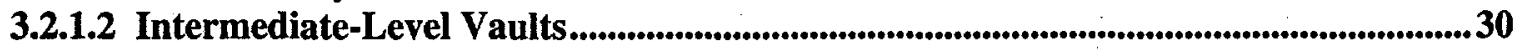

3.2.1.3 Very-Low-Activity Waste Disposal Trenches......................................................................30

3.2.1.4 Intimately-Mixed Cement-Stabilized Waste Disposal Trenches....................................32

3.2.1.5 Cement-Stabilized Encapsulated Waste Disposal Trenches ...........................................32

3.2.1.6 Naval Reactor Waste Pads ..................................................................................................32

3.2.2 Structural Stability and Inadvertent Intruder Barrier .................................................32

3.2.2.1 Low-Activity Waste Vaults............................................................................................32

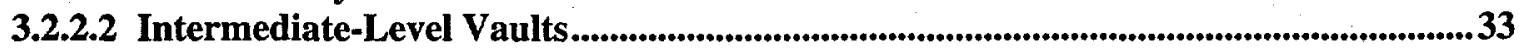

3.2.2.3 Very-Low-Activity Waste Disposal Trenches..............................................................33

3.2.2.4 Intimately-Mixed Cement-Stabilized Waste Disposal Trenches.....................................34

3.2.2.5 Cement-Stabilized Encapsulated Waste Disposal Trenches .........................................34

3.2.2.6 Naval Reactor Waste Pads ...............................................................................................34

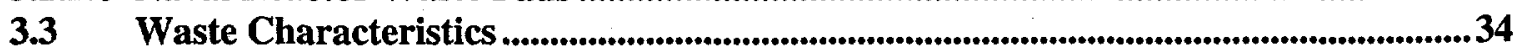

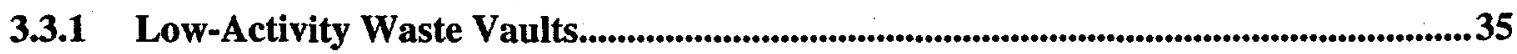

3.3.1.1 Waste Type/Chemical and Physical Form ...............................................................................35

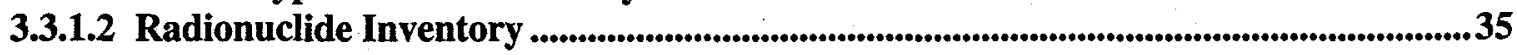

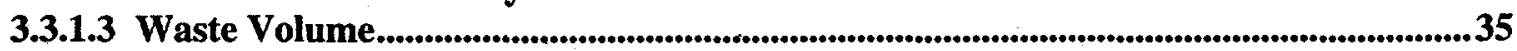

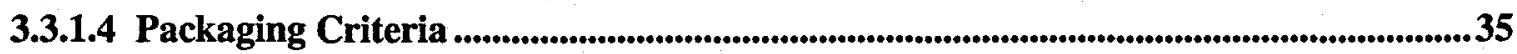

3.3.1.5 Pre-Disposal Treatment Methods.............................................................................................36 
3.3.1.6 Waste Acceptance Restrictions .......................................................................................36

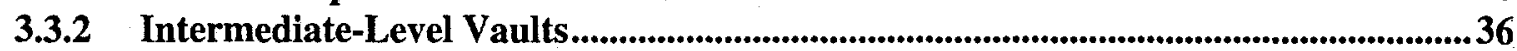

3.3.2.1 Waste Type/Chemical and Physical Form ...........................................................................36

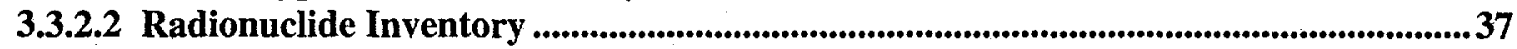

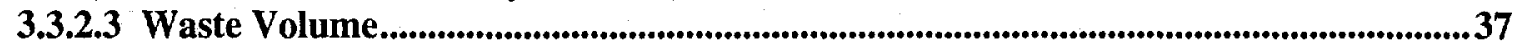

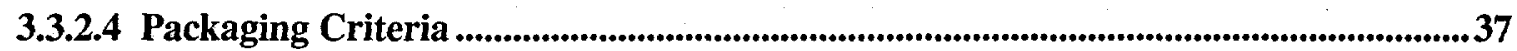

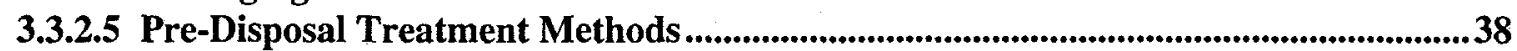

3.3.2.6 Waste Acceptance Restrictions .......................................................................................38

3.3.3 Very-Low-Activity Waste Disposal Trenches..................................................................38

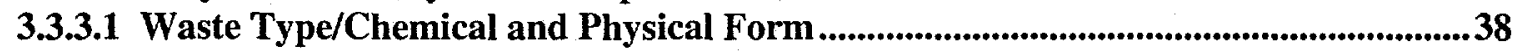

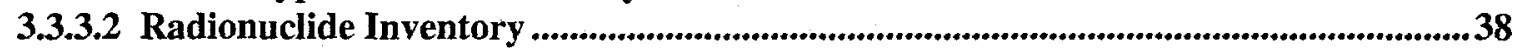

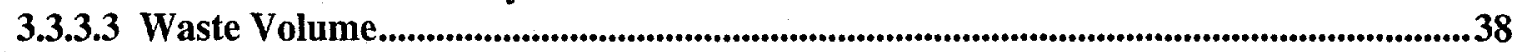

3.3.3.4 Packaging Criteria ..........................................................................................................38

3.3.3.5 Pre-Disposal Treatment Methods ............................................................................................38

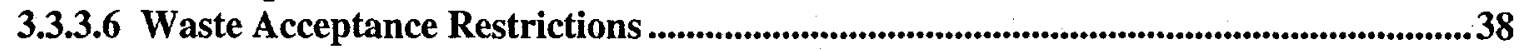

3.3.4 Intimately-Mixed Cement-Stabilized Waste Disposal Trenches....................................38

3.3.4.1 Waste Type/Chemical and Physical Form ...........................................................................39

3.3.4.2 Radionuclide Inventory ............................................................................................................. 39

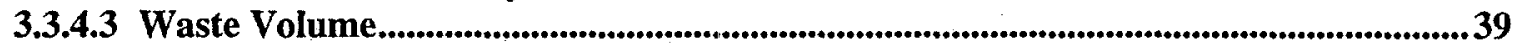

3.3.4.4 Packaging Criteria ..............................................................................................................39

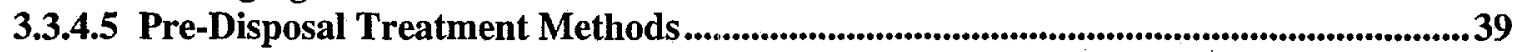

3.3.4.6 Waste Acceptance Restrictions ...........................................................................................39

3.3.5 Disposal Trenches for Cement-Stabilized Encapsulated Waste .....................................40

3.3.5.1 Waste Type/Chemical and Physical Form .........................................................................40

3.3.5.2 Radionuclide Inventory ................................................................................................40

3.3.5.3 Waste Volume.............................................................................................................................40

3.3.5.4 Packaging Criteria ...............................................................................................................40

3.3.5.5 Pre-Disposal Treatment Methods..............................................................................40

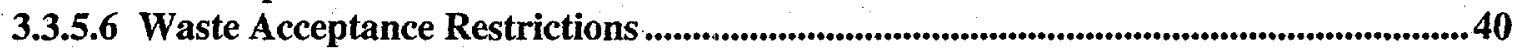

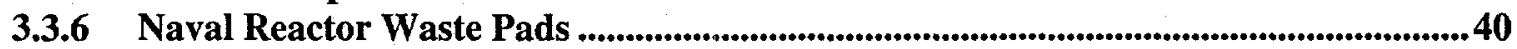

3.3.6.1 Waste Type/Chemical and Physical Form ...........................................................................40

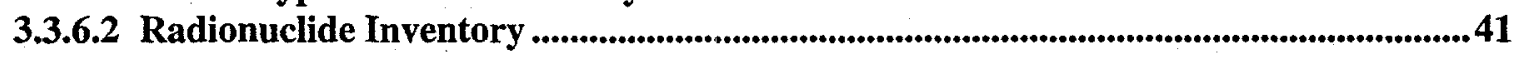

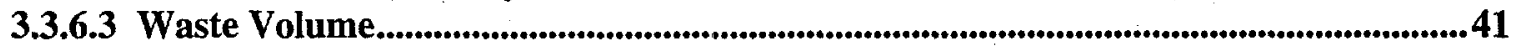

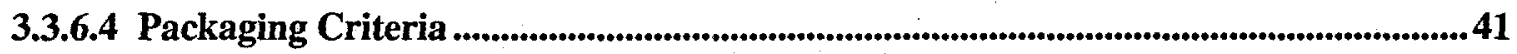

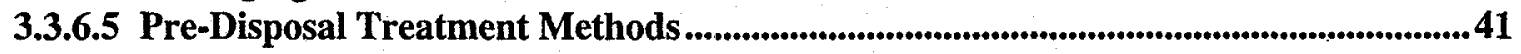

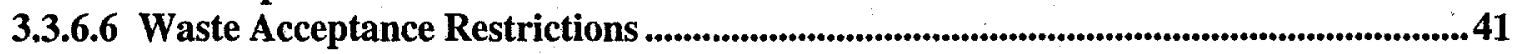

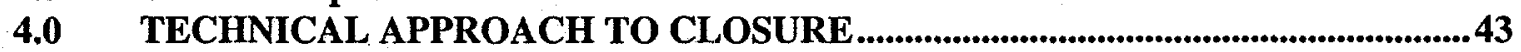

4.1 Compliance with Performance Objectives and Other Requirements ..........................43

4.1.1 All Pathways Dose .....................................................................................................................43

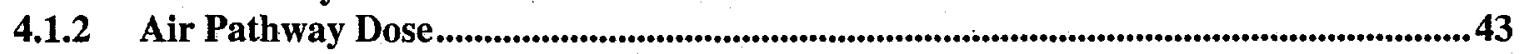

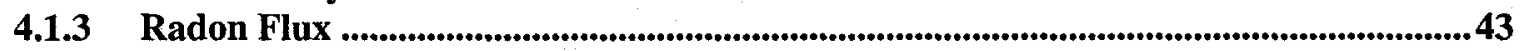

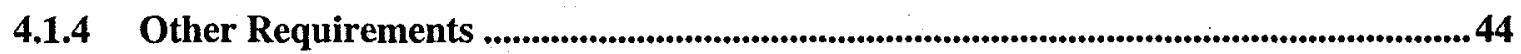

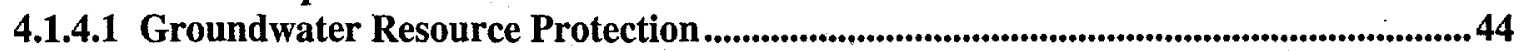

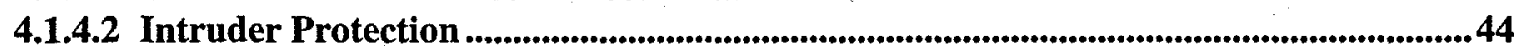

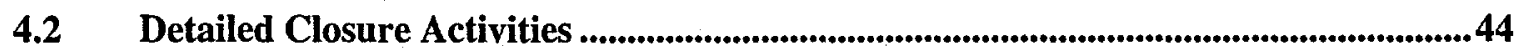

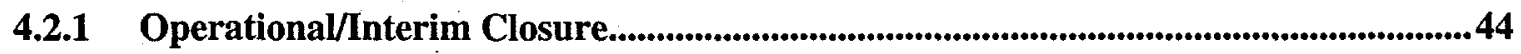

4.2.1.1 Trench Disposal Units..........................................................................................................44

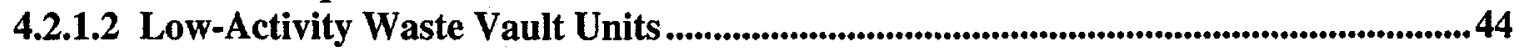

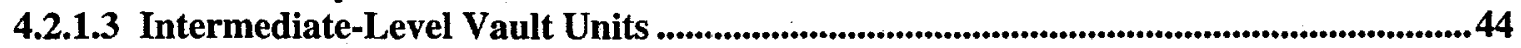

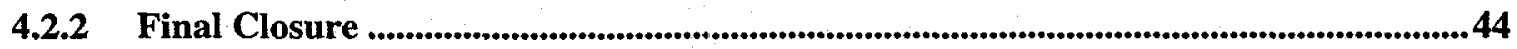

4.2.2.1 Cover System Design and Design Objectives.................................................................44 


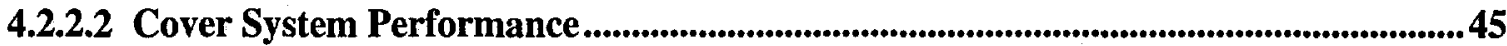

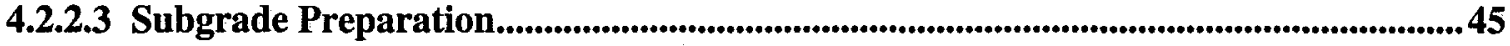

4.2.2.4 Cover System .....................................................................................................................446

4.2.2.5 Surface Drainage and Erosion Control..................................................................................48

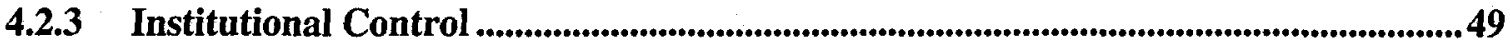

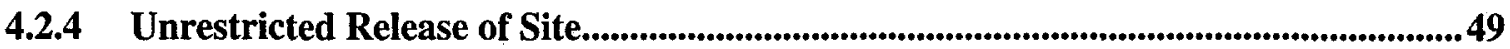

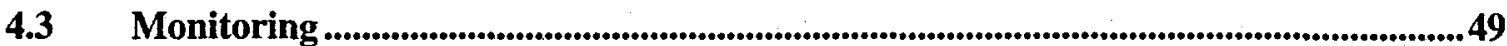

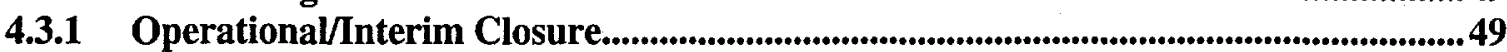

4.3.2 Final Closure/Institutional Care ...................................................................................49

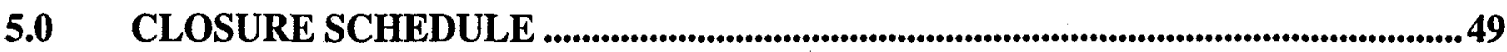

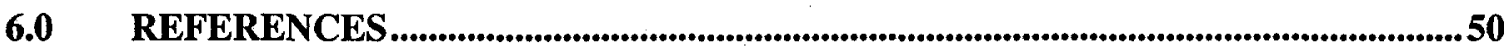

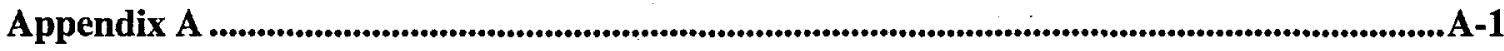

\section{LIST OF TABLES}

Table 3.1-1 Population Distribution and Percent of Region of Influence for Counties and Selected Communities..................................................................................................13

Table 3.1-2 Population Projections and Percent of Region of Influence..............................14

Table 3.1-3 Hydrostratigraphic Nomenclature ..............................................................................23

Table 3.1-4 Water Quality in the Savannah River Upstream and Downstream from SRS

(Calendar Year 1996).........................................................................................28

Table 3.1-5 Water Quality in Selected SRS Streams ..............................................................29

Table 3.2-1 Values for Hydraulic Properties of Vault Closure Design .................................31

Table 3.3-1 Forecast of Naval Reactor Waste Components for E-Area Low-Level Waste

Facility Disposal ..............................................................................................42

\section{LIST OF FIGURES}

Figure 3.1-1 Location of the E-Area Low-Level Waste Facility ............................................11

\section{LIST OF ACRONYMS AND ABBREVIATIONS}

$\begin{array}{ll}\text { ACRONYMS } & \\ \text { ASL } & \text { above mean sea level } \\ \text { CB/TS } & \text { core barrels/thermal shields } \\ \text { CERCLA } & \text { Comprehensive Environmental Response, Compensation, and Liability Act } \\ \text { CFR } & \text { Code of Federal Regulations } \\ \text { CIF } & \text { Consolidated Incinerator Facility } \\ \text { DAS } & \text { Disposal Authorization Statement } \\ \text { DCG } & \text { derived concentration guide } \\ \text { EPA } & \text { Environmental Protection Agency } \\ \text { GSA } & \text { General Separations Area } \\ \text { HD } & \text { holddown } \\ \text { HLW } & \text { High-Level Waste } \\ \text { IL } & \text { Intermediate-Level } \\ \text { ILNT } & \text { Intermediate-Level Non-Tritium } \\ \text { ILT } & \text { Intermediate-Level Tritium } \\ \text { KAPL } & \text { Knolls Atomic Power Laboratory } \\ \text { LAW } & \text { Low-Activity Waste } \\ \text { LLW } & \text { Low-Level Waste } \\ \text { LLWF } & \text { Low-Level Waste Facility }\end{array}$




\begin{tabular}{|c|c|}
\hline MCL & maximum contaminant level \\
\hline MMI & Modified Mercalli Intensity \\
\hline msl & mean sea level \\
\hline MWMF & Mixed Waste Management Facility \\
\hline NPDES & National Pollutant Discharge Elimination System \\
\hline NR & Naval Reactor \\
\hline NRC & Nuclear Regulatory Commission \\
\hline NWS & National Weather Service \\
\hline PA & Performance Assessment \\
\hline PSF & Pounds per square foot \\
\hline RCRA & Resource Conservation and Recovery Act \\
\hline ROI & Region of Influence \\
\hline SCDHEC & South Carolina Department of Health and Environmental Control \\
\hline SMCL & Secondary Maximum Contaminant Level \\
\hline SRS & Savannah River Site \\
\hline SWDF & Solid Waste Disposal Facility \\
\hline TSR & Technical Safety Requirement \\
\hline U.S. & United States \\
\hline USDA & United States Department of Agriculture \\
\hline USDOE & United States Department of Energy \\
\hline WAC & Waste Acceptance Criteria \\
\hline WQS & water quality standard \\
\hline \multicolumn{2}{|c|}{ UNIT ABBREVIATIONS } \\
\hline c & cubic \\
\hline c & centi \\
\hline $\mathrm{Ci}$ & Curie \\
\hline$f$ & foot, feet \\
\hline${ }^{0} \mathrm{~F}$ & degrees Fahrenheit \\
\hline g & gram \\
\hline gal & gallon \\
\hline in & inch \\
\hline $\mathbf{k}$ & kilo \\
\hline $\mathrm{km}$ & kilometer \\
\hline$L$ & liter \\
\hline $\mathrm{lb}$ & pound \\
\hline $\mathrm{m}$ & meter \\
\hline $\mathrm{mg}$ & milligram \\
\hline mrem & millirem \\
\hline $\mathrm{n}$ & nano \\
\hline NTU & nephelometric turbidity unit \\
\hline $\mathrm{p}$ & pico \\
\hline $\mathrm{R}$ & rem \\
\hline $\mathrm{s}$ & second \\
\hline$S$ & Siemen \\
\hline $\mathrm{yr}$ & year \\
\hline$\mu$ & micro \\
\hline
\end{tabular}




\subsection{EXECUTIVE SUMMARY}

A closure plan has been developed to comply with the applicable requirements of the U.S. Department of Energy (USDOE) Order 435.1 Manual and Guidance (USDOE 1999, USDOE 1999a). The plan is organized according to the specifications of the Format and Content Guide for U.S. Department of Energy Low-Level Waste Disposal Facility Closure Plans (USDOE 1999c).

Section 2 provides a brief overview of the general facility description, closure approach, closure schedule, related activities, and key assumptions. Sections 3 and 4 provide specific details of facility characteristics and the technical approach to closure as well as supporting information. Additional schedule details and references are provided in Sections 5 and 6.

The E-Area Low-Level Waste Facility (LLWF) is currently in the preliminary stages of operation. The level of detail in the closure plan is consistent with the fact that the facility is very early in its operational history. As the facility evolves and operational features are modified, the closure plan will be updated to reflect the current status of the facility. This will ensure that the closure concept is consistent with the ultimate facility configuration and design parameters as well as consistent with the Performance Assessment (PA) and compliant with applicable regulations at the time of closure.

\subsection{INTRODUCTION}

\subsection{General Facility Description}

The E-Area LLWF is the site for low-level radioactive waste disposal and storage at the Savannah River Site (SRS) and has been designed to manage all Low-Level Waste (LLW) resulting from SRS operations for the next 20 years.

Wastes disposed at the E-Area LLWF include containerized and uncontainerized waste forms. The facility is intended to provide containment to reduce radionuclide migration from disposed LLW forms. Low-Level Waste is disposed in concrete vaults and trenches. There are two types of vaults: the Low-Activity Waste (LAW) Vaults and the Intermediate-Level (IL) Vaults. In addition, the E-Area LLWF houses the E-Area Trenches and the Naval Reactor (NR) Waste Pads, as well as two types of enhanced trench disposal: Intimately-Mixed Cement-Stabilized Waste forms, such as Ashcrete and Blowcrete resulting from the operation of the Consolidated Incinerator Facility, and Cement-Stabilized Encapsulated Waste, where wasteforms will be disposed of in trenches surrounded by a grout or other cementitious material. Over the life of the E-Area LLWF, additional disposal units will be constructed as needed.

The disposal facility closure system will consist of interim/operational closure of certain sections of the facility as they are filled followed by backfilling and installation of a soil cover system designed to minimize moisture contact with the waste. The closure system includes drainage features, compacted soil layers, and a vegetative cover.

The E-Area LLWF site is located on a 200 -acre site immediately north of the former LLW burial site in an area of the SRS that is limited to industrial uses. Only 100 acres have been developed at this time; the additional 100 acres will allow for expansion of the LLW disposal capacity, as needed. The nearest SRS boundary to the E-Area LLWF is about $11 \mathrm{~km}$ to the west. The surrounding portions of the SRS are a mixture of industrial and administrative facilities as well as 
managed forestland. The general area adjacent to the SRS comprises forests, wetlands, water bodies, and unclassified predominantly rural lands.

The current SRS Future Use Plan states that the entire Savannah River Site will never be released for unrestricted use. In particular, the plan states that the central portion of the SRS, which includes the E-Area LLWF, will only be used for industrial purposes (USDOE 1998).

\subsection{General Closure Approach}

The closure system to be deployed at the E-Area LLWF includes consideration of the waste types, waste forms, facility location, site hydrogeologic properties, potential exposure scenarios, and lessons learned implementing closure systems at other facilities at the SRS. The actions taken immediately after a disposal unit is filled are specific to each disposal unit. Subsequently, a unified cover system will be constructed when the entire E-Area LLWF is filled.

In general, the waste types and forms play a key role in disposal facility design. Each of the various types of disposal units at the E-Area LLWF has been designed to handle a range of specific waste types. The PA evaluates the disposition of these various waste types and forms when disposed in the facility with the general closure system described in this plan in place. Various exposure scenarios are assessed and performance objectives are developed and tested against the facility design parameters. The closure cover system described in this closure plan has been developed based on the general design features included in the PA evaluation. Additional details have been added based on the current operational status of the facility. As operations continue, the closure plan will be updated to reflect the most current operational features that must be considered during closure.

Use of a soil capping system is a proven closure technique that has been implemented at other waste disposal facilities at the SRS. This type of closure system works in concert with the waste types and forms and the disposal facility features themselves to minimize moisture contact with the waste, divert surface water, prevent unauthorized access, and minimize long-term maintenance. Specific details of the closure system features are provided in Section 4.0.

\subsection{Closure Schedule}

The E-Area LLWF is in the very early stages of its planned operational life. This closure plan reflects the currently available information based on the facility's operational status. As operations continue, the closure plan will be updated to reflect the most current operational features that must be considered during closure. The schedule for final closure of the facility will be developed five years prior to completion of waste emplacement activities.

\section{$2.4 \quad$ Related Activities}

Operations at the E-Area LLWF will be managed to ensure that only waste meeting the criteria for classification as LLW will be disposed at the facility. There are currently no plans to handle any wastes that would invoke the requirements of the Resource Conservation and Recovery Act (RCRA). However, nearby/adjacent facilities are in various stages of compliance with both RCRA and Comprehensive Environmental Response, Compensation, and Liability Act (CERCLA) requirements based on former or current operations at these facilities.

Eventual closure and installation of the closure cover system for the E-Area LLWF will require coordination with these facilities to ensure that the closure system does not interfere with 
activities underway nearby. A multidisciplinary team of individuals cognizant of the current and, to the extent possible, the planned future activities at these facilities participated in the development and review of this closure plan. Continued interaction with personnel from these adjacent and nearby facilities is key to the success of the E-Area LLWF closure.

The closure system described in this closure plan is based on the concept discussed in the PA. This system is designed to meet the performance objectives set forth in the PA and the Disposal Authorization Statement (DAS) [USDOE 1999b]. The PA Maintenance Program (WSRC 2000b) reviews the PA and associated documents, such as monitoring and closure plans, and ensures that the activities associated with each are coordinated and that ancillary tasks needed to support the work described in these documents is planned for and implemented. In addition, the PA Maintenance Program will review developments in closure system design, construction, performance in the field, and other developments relevant to closure at the E-Area LLWF and apply them to the closure as necessary.

\subsection{Summary of Key Assumptions}

Key assumptions in the closure approach for the E-Area LLWF are the hydraulic properties of the closure cap system materials and the total thickness of the cap. The PA demonstrated compliance with the performance objectives using specific values for these key parameters. These values are reflected in the closure concept discussed in this plan.

Though technological improvements are likely to make alternatives to a layered soil cap more feasible, and perhaps, more cost effective, while still achieving the necessary hydraulic properties to meet the performance objectives, it is important to maintain the total cap thickness assumed in the PA. This thickness is necessary for shielding in the inadvertent intruder scenario.

An additional key assumption of the PA is the time of failure used for the waste units. However, this assumption is not integral to the closure concept design or implementation because the PA assumes that any closure system fails along with failure of the disposal unit.

Further details of the specific relationships between these key assumptions and closure design are provided in Section 4 of this plan. Specific details of these assumptions and their role in the PA are provided in the PA.

\subsection{DISPOSAL FACILITY CHARACTERISTICS}

Per the guidance for preparation of LLW facility closure plans, this section summarizes information in the facility PA, which is referenced periodically throughout this section and listed in the reference section. For source references of specific data cited from the PA, refer to the PA (WSRC 2000).

\subsection{Site Characteristics}

Evaluation of radionuclide transport from the E-Area LLWF, and of human exposure resulting from release of radionuclides to the environment, requires careful consideration of factors affecting transport processes and exposure potential. Topographic features and hydrogeologic characteristics strongly affect the direction and flow of radionuclides potentially released from the disposal site. Projected land use and population distributions affect the estimation of human exposure. In this section, the relevant natural and demographic characteristics of the E-Area site and surrounding area are discussed. 


\subsubsection{Geography and Demography}

\subsubsection{Disposal Site Location}

The SRS occupies about $780 \mathrm{~km}^{2}$ in Aiken, Barnwell, and Allendale Counties on the Upper Atlantic Coastal Plain of southwestern South Carolina. The center of the SRS is approximately 36 $\mathrm{km}$ southeast of Augusta, GA; $32 \mathrm{~km}$ south of Aiken, SC; $160 \mathrm{~km}$ from the Atlantic Coast; and is bounded on the southwest by the Savannah River for about $28 \mathrm{~km}$. The Fall Line, which separates the Atlantic Coastal Plain physiographic province from the Piedmont physiographic province, is approximately $50 \mathrm{~km}$ northwest of the central SRS (Fig. 3.1-1).

Prominent geographic features within $80 \mathrm{~km}$ of the SRS are the Savannah River, Thurmond Lake, Par Pond, and L Lake. The Savannah River forms the southwest boundary of the SRS. Thurmond Lake is the largest nearby public recreational area. This reservoir is on the Savannah River and is about $64 \mathrm{~km}$ upstream of the center of the SRS. Par Pond is an $11 \mathrm{~km}^{2}$ former reactor cooling water impoundment that lies in the eastern sector of the SRS. L Lake is a $4 \mathrm{~km}^{2}$ former reactor cooling water impoundment that lies in the southern sector of the SRS.

The E-Area LLWF is located in the central region of the SRS known as the General Separations Area (GSA). The disposal site consists of approximately $0.8 \mathrm{~km}^{2}$ (200 acres) and is situated immediately north of the former LLW burial grounds. Construction of the E-Area LLWF began in October 1989. Planned construction covers an elbow-shaped, cleared area of $0.4 \mathrm{~km}^{2}(100$ acres), curving to the northwest on an interfluvial plateau.

\subsubsection{Disposal Site Description}

The elevation of the SRS ranges from $24 \mathrm{~m}$ above msl (ASL) at the Savannah River to about 122 $\mathrm{m}$ ASL in the upper northwest portion of the site. The Pleistocene Coastal terraces and the Aiken Plateau form two distinct physiographic subregions at the SRS (WSRC 2000). The Pleistocene Coastal terraces are below $82 \mathrm{~m}$ in elevation, with the lowest terrace constituting the present flood plain of the Savannah River and the higher terraces characterized by gently rolling topography. The relatively flat Aiken Plateau occurs above $82 \mathrm{~m}$.

The Aiken Plateau is dissected by numerous streams. Because of the large number of tributaries to small streams on the SRS, no location on the site is far from a flowing stream, most of which drain to the Savannah River.

The E-Area site has low to moderate topographic relief and is drained by several perennial streams (Fig. 3.1-1). It slopes from an elevation of about $88 \mathrm{~m}$ in the southernmost corner to an elevation of $76 \mathrm{~m}$ in the northernmost corner. The site is bordered by three streams with several intermittent streams present within the area boundary. Runoff is to the north toward Upper Three Runs, to the east toward Crouch Branch, and to the west toward an unnamed branch. Upper Three Runs is approximately $760 \mathrm{~m}$ north of the facility boundary. The nearest perennial stream is approximately $370 \mathrm{~m}$ northeast of the boundary.

The dominant vegetation on the SRS is forest, with types ranging from scrub oak communities on the driest areas to bald cypress and black gurn in the swamps. Pine forests cover more area than any other forest type. Land utilization presently is about 56 percent in pine forests, 35 percent in hardwoods, 7 percent in SRS facilities and open fields, and 2 percent in water (WSRC 2000). 


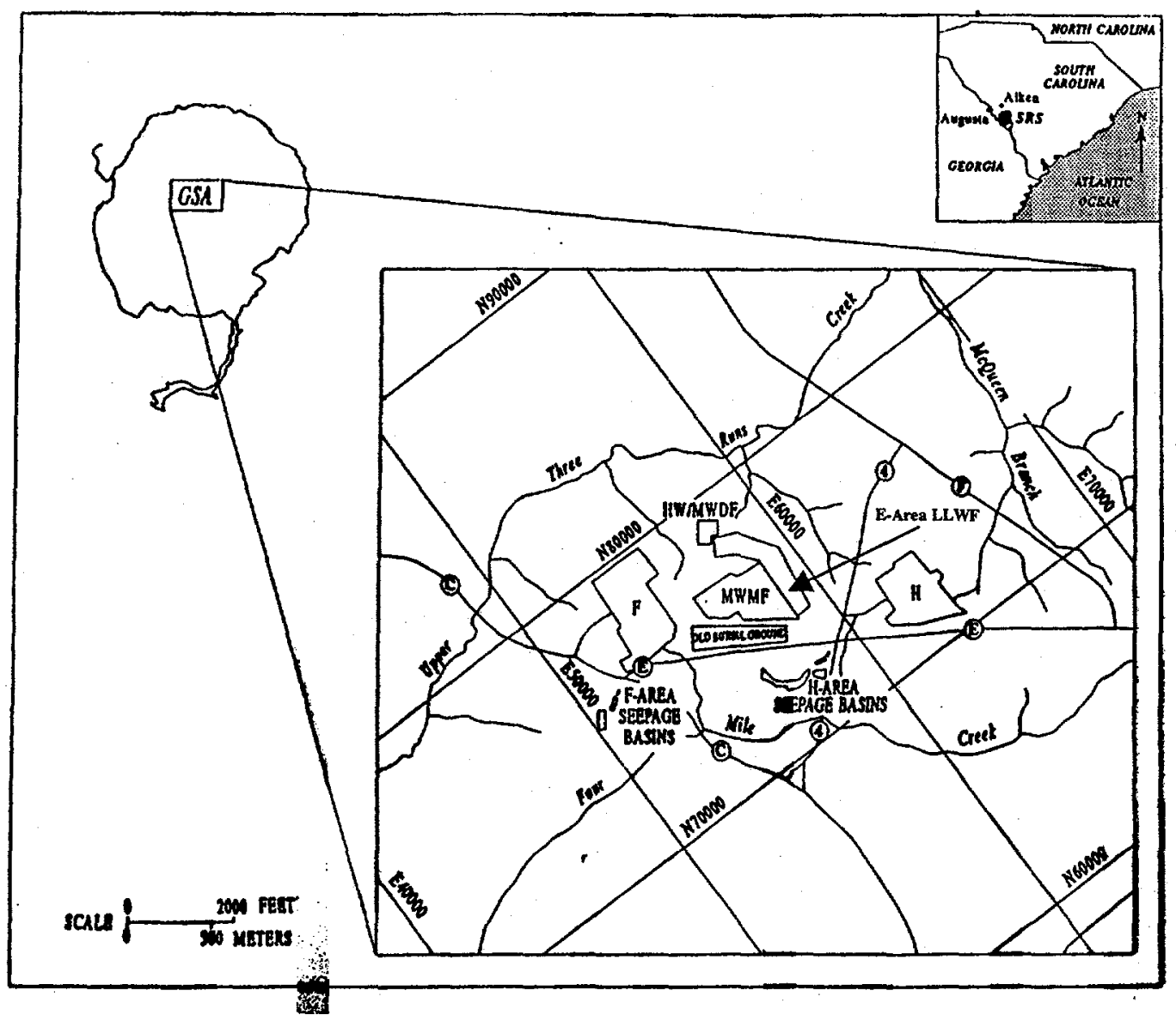

Figure 3.1-1 Location of the E-Area Low-Level Waste Facility

Rev. 1 
Except for three roadways and a railway that are near the edge of the SRS, public access to the SRS is restricted to guided tours, controlled deer hunts, and authorized environmental studies. The major production areas located at the site include: Raw Materials (M Area), Separations (F and $\mathrm{H}$ Areas), Waste Management Operations (E, F, and $\mathrm{H}$ Areas), and Defense Waste Processing ( $\mathrm{S}$ and $\mathrm{Z}$ Areas). Administrative and support services, the Savannah River Technology Center, and the Savannah River Ecology Laboratory are located in A Area.

\subsubsection{Population Distribution}

Based on state and federal agency surveys and trends, the estimated 1994 population in the region of influence was 457,824. More than 89 percent lived in Aiken (28.8 percent), Columbia (17.5 percent), and Richmond (42.8 percent) counties (Table 3.1-1). The population in the region grew at an average annual growth rate of 1.2 percent during the $1980 \mathrm{~s}$ and slowed to a less than 1 percent rate between 1990 and 1994. The positive net immigration that occurred in the region was consistent with population growth in Georgia and South Carolina. Columbia County experienced the greatest increase, 146 percent total net increase. Aiken County was second with a 53 percent total net increase. Over the same period, however, Bamberg, Barnwell, and Richmond counties experienced a net loss of population.

Population projections indicate that the overall population in the region should continue to grow until about 2040. Three counties-Allendale, Bamberg, and Barnwell-should experience little growth after 2000, while the others should increase consistently (Table 3.1-2). Columbia County will continue to show a significant upward growth pattern (WSRC 2000).

\subsubsection{Uses of Adjacent Lands}

In the area adjacent to the SRS, less than 8 percent of the existing land is devoted to urban and built-up uses. Most such uses are in and around the cities of Augusta and Aiken. Agriculture accounts for about 21 percent of total land use; forests, wetlands, water bodies, and unclassified, predominantly rural, lands account for about 70 percent.

The projected future land uses of the area adjacent to the SRS are similar to existing patterns. Developed urban land is projected to increase by 2 percent in the next 20 years. The largest percentage of this growth is expected to occur in Aiken and Columbia Counties as a result of the expansion of the Augusta metropolitan area (WSRC 2000).

\section{$\underline{3.1 .2} \quad$ Meteorology and Climatology}

The southeastern United States has a humid, subtropical climate characterized by relatively short, mild winters and long, warm, and humid summers. Summer-like weather typically lasts from May through September, when the area is subject to the persistent presence of the Atlantic subtropical anticyclone (i.e., the "Bermuda" high). The humid conditions often result in scattered afternoon thunderstorms. Average seasonal rainfall is usually lowest during the fall.

The weather is changeable during the winter as mid-latitude low-pressure systems and fronts migrate through the region. Measurable snowfall is rare. Spring is characterized by a higher frequency of tornadoes and severe thunderstorms than the other seasons. During spring, temperatures are mild and the humidity is relatively low. 
Table 3.1-1 Population Distribution and Percent of Region of Influence for Counties and Selected Communities

\begin{tabular}{lrr}
\hline Jurisdiction & 1994 Population & 1994 \%ROI \\
\hline South Carolina & $3,663,990$ & \\
Aiken County & 132,060 & 28.8 \\
Aiken & 24,930 & 5.4 \\
Jackson & 1,880 & 0.4 \\
New Ellenton & 2,490 & 0.5 \\
North Augusta & 17,610 & 3.8 \\
Allendale County & 11,690 & 2.6 \\
Bamberg County & 16,700 & 3.6 \\
Barnwell County & 21,420 & 4.7 \\
$\quad$ Barnwell & 5,600 & 1.2 \\
Georgia & $7,055,340$ & \\
Columbia County & 79,920 & 17.5 \\
Augusta/Richmond & 196,030 & 42.8 \\
County & & \\
Six-county total & & \\
United States & & \\
\hline NOTES: & & \\
ROI - Region of Influence & & \\
SOURCE: & & \\
WSRC 2000 & & \\
\hline
\end{tabular}

Rev. 1 
Table 3.1-2 Population Projections and Percent of Region of Influence

\begin{tabular}{|c|c|c|c|c|c|c|c|c|c|c|}
\hline \multirow[b]{2}{*}{ Jurisdiction } & \multicolumn{2}{|l|}{2000} & \multicolumn{2}{|l|}{2010} & \multicolumn{2}{|l|}{2020} & \multicolumn{2}{|l|}{2030} & \multicolumn{2}{|l|}{2040} \\
\hline & Population & $\% \mathrm{ROI}$ & Population & $\% \mathrm{ROI}$ & Population & $\% \mathrm{ROI}$ & Population & $\% \mathrm{ROI}$ & Population & $\% \mathrm{ROI}$ \\
\hline \multicolumn{11}{|l|}{ South Carolina } \\
\hline Aiken County & 133,760 & 26.81 & 145,800 & 26.35 & 156,590 & 26.22 & 168,180 & 26.19 & 180,620 & 26.07 \\
\hline $\begin{array}{l}\text { Allendale } \\
\text { County }\end{array}$ & 12,960 & 2.60 & 14,130 & 2.55 & 15,180 & 2.54 & 16,300 & 2.54 & 17,510 & 2.53 \\
\hline Bamberg County & 18,690 & 3.75 & 20,380 & 3.68 & 21,880 & 3.66 & 23,500 & 3.66 & 25,240 & 3.64 \\
\hline Barnwell County & 22,440 & 4.50 & 24,460 & 4.42 & 26,270 & 4.40 & 28,220 & 4.39 & 30,310 & 4.37 \\
\hline \multicolumn{11}{|l|}{ Georgia } \\
\hline $\begin{array}{l}\text { Columbia } \\
\text { County }\end{array}$ & 80,290 & 16.10 & 90,010 & 16.27 & 97,390 & 16.31 & 105,376 & 16.41 & 114,020 & 16.46 \\
\hline $\begin{array}{l}\text { Richmond } \\
\text { County }\end{array}$ & 230,700 & 46.25 & 258,610 & 46.73 & 279,820 & 46.86 & 300,526 & 46.80 & 325,170 & 46.93 \\
\hline Six-county total & 498,850 & 100 & 533,390 & 100 & 597,130 & 100 & 642,098 & 100 & 692,860 & 100 \\
\hline $\begin{array}{l}\text { NOTES: } \\
\text { ROI - Region of Inf } \\
\text { SOURCE: } \\
\text { WSRC } 2000 \\
\end{array}$ & ence & & & & & & & & & \\
\hline
\end{tabular}


Sources of data used to characterize the climatology of the SRS consist of a standard instrument shelter in A Area (temperature, humidity, and rainfall for 1961 to 1994), the Central Climatology Meteorological Facility near N Area (temperature, humidity, and precipitation for 1995-1996), and the $\mathrm{H}$-Area meteorological tower (winds and atmospheric stability).

The average annual temperature at the SRS is $64.7^{\circ} \mathrm{F}$. July is the warmest month of the year with an average daily maximum of $92^{\circ} \mathrm{F}$ and an average daily minimum near $72^{\circ} \mathrm{F}$. January is the coldest month with an average daily high around $56^{\circ} \mathrm{F}$ and an average daily low of $36^{\circ} \mathrm{F}$. Temperature extremes recorded at the SRS since 1961 are $107^{\circ} \mathrm{F}$ in July 1986 and $-3^{\circ} \mathrm{F}$ in January 1985.

Annual precipitation averages 49.5 inches. Summer is the wettest season of the year with an average monthly rainfall of 5.2 inches. Fall is the driest season with an average monthly rainfall of 3.3 inches. Relative humidity averages 70 percent annually with an average daily maximum of 91 percent and an average daily minimum of 45 percent.

Winds are most frequently from the northeast and southwest sectors. Measurements of turbulence are used to determine whether the atmosphere has relatively high, moderate, or low potential to disperse airborne pollutants (commonly identified as unstable, neutral, or stable atmospheric conditions, respectively). Generally, SRS atmospheric conditions were categorized as unstable 56 percent of the time (WSRC 2000).

Meteorological data are critical input to atmospheric transport and dose models that are used to estimate the effects of releases from SRS facilities. The atmospheric transport and dose modeling performed for this PA is based upon a 5-year average meteorological dataset from the period 1987 to 1991 . This quality-assured meteorological database is the most recent for the SRS.

An average of 54 thunderstorm days per year were observed at the National Weather Service (NWS) Augusta, GA, office during the period 1951-1995. About half of the thunderstorms occurred during the summer. Since operations began at the SRS, ten confirmed tornadoes have occurred on or in close proximity to the site. Several of these tornadoes were estimated to have winds up to 150 miles per hour and did considerable damage to forested areas of the SRS. None caused damage to structures. Tornado statistics indicate that the average frequency of a tornado striking any single point on the site is $7.11 \times 10^{-5}$ per year or about once every 14,000 years (WSRC 2000).

The highest sustained wind recorded at the Augusta NWS Office is 82 miles per hour. The maximum 100-year straight-line wind speed for the SRS area has been estimated to be 107 miles per hour. Straight-line winds are produced by hurricanes, thunderstorms, and strong winter storms. Hurricanes struck South Carolina 36 times during the period 1700 to 1992, an average recurrence frequency of once every 8 years. A hurricane force wind of 75 miles per hour has been observed at SRS only once, during Hurricane Gracie in 1959.

\section{$\underline{\text { 3.1.3 } \quad \underline{E c o l o g y}}$}

\subsubsection{Aquatic Ecology}

Flora in the Savannah River basin and in creeks on the SRS is diverse and seasonally variable. Several species of diatoms, green algae, yellow-green algae, and blue-green algae are present. In seasonally flooded areas, bald cypress and tupelo gum thrive. In less severely flooded areas, oak, 
maple, ash, sweet gum, ironwood, and other species less tolerant of flooding are found. In the river swamp formed by the Savannah River in the vicinity of the SRS, herbaceous growth is sparse. A number of macrophytes, such as cattail and milfoil, are found in areas receiving sufficient sunlight.

The fish communities in the Savannah River and in creeks on the SRS are very diverse. Redbreast sunfish, spotted sucker, channel catfish, and flat bullhead are the dominant species. Sunfish, crappies, darters, minnows, American shad, and striped bass are also abundant.

Macroinvertebrate communities are largely comprised of true flies, mayflies, caddisflies, stoneflies, and beetles. Leaf litter input is high but is rapidly broken down by macroinvertebrate shredders. The Asiatic clam is found in the Savannah River and its larger tributary streams.

\subsubsection{Terrestrial Ecology}

Prior to its acquisition by the United States (U.S.) Government in 1951, approximately one-third of the SRS was cropland, about half was forested, and the remainder was floodplain and swamp. Since that time, the U.S. Forest Service has reclaimed many previously disturbed areas through natural plant succession or by planting pine trees. As was noted in Section 3.1.1.2, 91 percent is now pine or hardwood forests, with the remaining 9 percent divided between SRS facilities and water bodies.

A variety of vascular plants exist on the site. Scrub oak communities cover the drier sandy areas, which include predominantly longleaf pine, turkey oak, bluejack oak, blackjack oak, dwarf post oak, three awn-grass, and huckleberry. On the more fertile, dry uplands, white oak, post oak, southern red oak, mockernut hickory, pignut hickory, and loblolly pine predominate, with an understory of sparkleberry, holly, greenbriar, and poison ivy. Pine trees cover more area than any other tree genus (WSRC 2000).

The heterogeneity of the vegetation on the SRS supports a diverse wildlife population. Several species of reptiles and amphibians are present due to the variety of aquatic and terrestrial habitats. These include snakes, frogs, toads, salamanders, turtles, lizards, and alligators. More than 213 species of birds have been identified on the SRS. Burrowing animals at the SRS include: Peromyscus polionotus, known commonly as the Old Field Mouse; Blarine brevicauda, known as the short tail shrew; Scalopus aquiticus, known as the eastern mole; Pogonomyrmex badius, known as the harvester ant; Dorymyrmex pyramicus, known as the pyramid ant; and earthworms (WSRC 2000).

\section{$\underline{3.1 .4 \quad \text { Geology }}$}

\subsubsection{Regional and Site-Specific Geology/Topography}

The surface of the Upper Atlantic Coastal Plain on which the SRS is located slopes gently seaward. The province is underlain by a seaward dipping wedge of unconsolidated and semiconsolidated sediments that extends from the Fall Line to the seaward edge of the continental shelf. Sediment thickness increases from zero at the Fall Line, where the crystalline Piedmont province gives way to the Coastal Plain, to more than $1.2 \mathrm{~km}$ near the coast of South Carolina. The SRS is underlain by about 180 to $370 \mathrm{~m}$ of Coastal Plain sediments. These sediments vary in age from Late Cretaceous to Miocene and are divided into several groups based principally on age and lithology. A brief discussion of these groups follows. The presence and approximate thicknesses of the sediments in the vicinity of E Area are also provided. An in-depth treatment of 
the stratigraphy of the SRS is given in a recent report by the State of South Carolina's Department of Natural Resources (Aadland et al. 1995).

\section{Late Cretaceous Sediments}

The Late Cretaceous sediments include, from oldest to youngest, the Cape Fear Formation and the three formations of the Lumbee Group: the Middendorf, Black Creek, and Steel Creek Formations. These sediments are approximately $210 \mathrm{~m}$ thick at the center of the SRS, near E Area. The lowermost Cape Fear Formation rests on a thin veneer of saprolitic bedrock, which defines the surface of the crystalline and sedimentary basement rock. This formation is composed of poorly sorted silty-to-clayey quartz sands and interbedded clays. Bedding thicknesses range from 1.5 to $6 \mathrm{~m}$, with sand beds being thicker than clay beds. The formation is about $9 \mathrm{~m}$ thick at the northwestern boundary of the SRS, and it increases to more than $55 \mathrm{~m}$ near the southeastern boundary. This formation has not been observed to outcrop in the vicinity of the SRS (WSRC 2000).

The thickness of the Lumbee Group, which overlies the Cape Fear Formation, varies across the SRS from $120 \mathrm{~m}$ in the northwest to more than $230 \mathrm{~m}$ near the southeastern boundary. The Middendorf Formation, which directly overlies the Cape Fear Formation, is composed mostly of medium and coarse quartz sand that is cleaner and less indurated than the underlying sediments. Clay casts and pebbly zones occur in several places in the Middendorf Formation. A clay zone up to $24 \mathrm{~m}$ thick forms the top of this formation over much of the SRS. In total, the Middendorf Formation ranges from approximately 40 to $55 \mathrm{~m}$ thick from the northwestern to southeastern boundary of the SRS. Outcrops of this formation have been identified northwest of the SRS (WSRC 2000).

The Black Creek Formation consists of quartz sands, silts, and clays. The lower section consists of fine- to coarse-grained sands with layers of pebbles and clay casts. The upper section changes in composition as it crosses the SRS from northwest to southeast, from massive clay to silty sand with interbeds of clay. Thickness of the Black Creek Formation under the SRS ranges from $34 \mathrm{~m}$ in the northwest to $76 \mathrm{~m}$ in the southeast. Outcropping in the vicinity of the SRS has not been confirmed (WSRC 2000).

The uppermost formation in the Lumbee Group is the Steel Creek Formation (previously referred to as the Peedee Formation), which consists of fine-grained sandstone and siltstone with marine fossils. This formation is comparable in age, but lithologically distinct, from the Peedee Formation in southwestern South Carolina. The lower portion of this formation consists of fineto coarse-grained quartz sand and silty sand, with a pebble-rich zone at its base. Pebbly zones and clay casts are common throughout the lower portion of the Steel Creek Formation. The upper portion of this formation is a clay that varies from more than $15 \mathrm{~m}$ to less than $1 \mathrm{~m}$ in thickness at the SRS. The Steel Creek Formation is about $34 \mathrm{~m}$ thick at the northwestern SRS boundary and about $40 \mathrm{~m}$ thick at the southeastern boundary. No nearby outcropping has been identified (WSRC 2000).

\section{Paleocene-Eocene Black Mingo Group}

Paleocene-Early Eocene sediments make up the Black Mingo Group. In E Area, this group consists of the Early Paleocene Lang Syne/Sawdust Landing Formations, the Late Paleocene Snapp Formation, and the Early Eocene Fourmile Formation. This group is about $21 \mathrm{~m}$ thick at the northwestern SRS boundary, thickens to about $46 \mathrm{~m}$ near the southeastern boundary, and is about $210 \mathrm{~m}$ thick at the coast (WSRC 2000). 
The Lang Syne/Sawdust Landing Formations together are equivalent to the lithologic unit previously referred to as the Ellenton Formation (WSRC 2000). These formations, treated as a single unit due to difficulty in mapping them separately (Aadland et al. 1995), consist mostly of gray, poorly sorted, micaceous, lignitic, silty and clayey quartz sand interbedded with gray clays. They are approximately $12 \mathrm{~m}$ thick at the northwestern boundary of the SRS and thicken to about $30 \mathrm{~m}$ near the southeastern boundary. These formations outcrop about four miles northwest of the SRS.

The deposits near the SRS that are time-equivalent to the Williamsburg Formation differ from the type Williamsburg and are designated as the Snapp Formation. The sediments are typically silty, medium- to coarse-grained quartz sand interbedded with clay. The Snapp Formation pinches out at the northwestern SRS boundary and thickens to about $15 \mathrm{~m}$ near the southeastern boundary. In E Area, the distribution of the Snapp Formation is sporadic, not continuous.

Sand immediately overlying the Snapp Formation is identified as the Fourmile Formation. The well-sorted sand of this formation is an average of $9 \mathrm{~m}$ in thickness. Clay beds near the middle and top of the formation are a few feet thick. In E Area, this formation may not be continuous.

\section{Middle Eocene Orangeburg Group}

The middle Eocene sediments make up the Orangeburg Group, which in E Area consists of the lower middle Eocene Congaree Formation, the upper middle Eocene Warley Hill Formation, and the late middle Eocene Tinker/Santee Limestone Formation. The sediments thicken from about $30 \mathrm{~m}$ at the northwestern SRS boundary to about $49 \mathrm{~m}$ near the southeastern boundary (Aadland et al. 1995). The dip of the upper surface of this formation is about $.002 \mathrm{~m} / \mathrm{m}$ to the southeast across the site. The Orangeburg Group is about $100 \mathrm{~m}$ thick at the coast. The group outcrops at lower elevations in many places near and on the SRS.

The Congaree Formation consists of fine to coarse, well-sorted and rounded quartz sands. Thin clay laminae occur throughout, as do small pebble zones. The sand is glauconitic in places. The formation is about $26 \mathrm{~m}$ thick at the center of the SRS (WSRC 2000).

The Warley Hill Formation, made up of glauconitic sand and green clay beds and thus previously referred to as the "green clay," overlies the Congaree Formation. This formation is generally 3 to $6 \mathrm{~m}$ in thickness. However, northwest of E Area, the Warley Hill Formation is missing or very thin, such that the overlying Tinker/Santee Formation rests unconformably on the Congaree Formation.

The Tinker/Santee Formation consists of calcilutite, calcarenite, shelly limestone, calcareous sands and clays, and micritic limestone. The sands are glauconitic in places and fine- to medium-grained. The sediments comprising this formation have been referred to in the past as the Santee Limestone, McBean, and Lisbon Formations and indicate deposition in shallow marine environments. The Tinker/Santee Formation is about 12 to $15 \mathrm{~m}$ thick in the center of $\mathrm{E}$ Area (WSRC 2000). In places where the Warley Hill Formation is absent, the Tinker/Santee Formation rests directly on the Congaree Formation.

\section{Late Eocene Barnwell Group}

The Late Eocene sediments make up the Barnwell Group, which consists of the Clinchfield, Dry Branch, and Tobacco Road Sand. The Clinchfield Formation, the oldest of the three, is made up 
of quartz sand, limestone, calcareous sand, and clay. It is generally identified only when the contrasting carbonates of the overlying Dry Branch and underlying Tinker/Santee Formations are present, with the sand of the Clinchfield Formation sandwiched between them. It has been identified at several areas within the SRS, where it is up to $8 \mathrm{~m}$ thick, but is indistinguishable in the central regions of the SRS, near E Area.

The Dry Branch Formation consists of three distinguishable members: the Twiggs Clay Member, the Griffins Landing Member, and the Irwinton Sand Member. The Twiggs Clay Member is not mapable as a continuous unit within the SRS, but lithologically similar clay is present at various levels within this formation. The tan, light gray, and brown clay of the Twiggs Clay Member has previously been referred to as the "tan clay" at the SRS. The Griffins Landing Member is up to 15 $m$ thick in the southeastern part of the SRS. This member consists mostly of calcilutite and calcarenite, calcareous quartz sand, and slightly calcareous clay. It occurs sporadically and pinches out in the center of the SRS. The remainder of the Dry Branch Formation within the SRS is made up of the Irwinton Sand Member, which is composed of moderately sorted quartz sand, with interlaminated clays abundant in places. Clay beds of this member have also been referred to as the "tan clay" at the SRS. The Irwinton Sand is about $12 \mathrm{~m}$ thick at the northwestern SRS boundary and thickens to $21 \mathrm{~m}$ near the southeastern boundary. It outcrops in many places around and within the SRS.

The Tobacco Road Sand overlies the Dry Branch Formation. This formation consists of moderately to poorly sorted quartz sands, interspersed with pebble layers and clay laminae. The sediments have the characteristics of a shallow marine deposit. The upper surface of this formation is irregular due to an incision that accompanied deposition of the overlying "Upland Unit" and later erosion. The thickness is variable as a result of erosive processes, but is at least $15 \mathrm{~m}$ in places (WSRC 2000).

\section{"Upland Unit"}

The "Upland Unit" is an informal stratigraphic term applied to terrestrial deposits that occur at higher elevations in some places in the southwestern South Carolina Coastal Plain. This unit overlies the Barnwell Group in the Upper Coastal Plain of western South Carolina, on which the SRS is located. This unit occurs at the surface at higher elevations in many places around and within the SRS, but it is not present at all higher elevations. The sediments are poorly sorted, clayey-to-silty sands, with lenses and layers of conglomerates, pebbly sands, and clays. Clay casts are abundant. The "Upland Unit" is up to $21 \mathrm{~m}$ thick in parts of the SRS. Much of this unit corresponds to the Hawthorne Formation and the Tertiary alluvial gravels identified in previous documents (WSRC 2000).

$\underline{\text { Soils }}$

Most of the soils at the SRS are sandy over a loamy or clayey subsoil. The distribution of soil types is very much influenced by the creeks on the site, with colluvial deposits on hilltops and hillsides giving way to alluvium in valley bottoms (WSRC 2000). Road cuts and excavations on interstream areas near the SRS commonly expose a deeply developed soil profile. Two horizons are apparent. The A horizon may be up to $3 \mathrm{~m}$ thick and typically consists of structureless fine- to medium-grained quartz sand, and the lower B horizon, which may be from 0.6 to $3 \mathrm{~m}$ in thickness, contains iron and aluminum compounds leached from the overlying material.

Weathering effects are evident. In some areas, intense weathering has produced tensional soil fractures as a result of volume reduction. These fractures are dominant features in shallow 
exposures such as drainage ditches or roadside embankments. Average soil erosion rates for the area surrounding the SRS, much of which is cropland, range from 1.5 to $2.0 \mathrm{~kg} / \mathrm{m}^{2} / \mathrm{yr}$. The PA provides an estimate predicting that the presence of natural successional forests would reduce erosion by a factor of 400 to 500 over cropland erosion.

\section{$\underline{\text { Seismology }}$}

The susceptibility of the SRS, and particularly E Area, to seismic motion is of interest to establish if E Area is suitable for waste disposal. Seismic events could result in cracking of the encapsulating material. Cracking could be fairly severe if liquefaction of supporting soils were to take place. However, liquefaction of supporting soils is not considered to be a potential problem at the SRS based on a review of previous studies at the SRS. Following is a discussion of seismic zones that are known to exist in the vicinity of the SRS and the expected intensity associated with seismic activity in these zones at the SRS.

\section{Location of Nearby Seismic Zones}

The SRS is located in the interior of the North American plate. In the past 200 years, the nearest zones of concentrated seismic activity in the region have been centered in the CharlestonSummerville area of South Carolina and near Bowman, SC, which is $60 \mathrm{~km}$ northwest of Summerville, SC. Recent seismic activity in the Charleston area, probably including the earthquake of 1886, has originated largely or entirely in the basement beneath the Coastal Plain sediments. The seismicity in the Charleston area is believed to occur at the intersection of the Ashley River fault and the Woodstock fault, at minimum depths of $4 \mathrm{~km}$ and $8 \mathrm{~km}$, respectively. Seismicity associated with the Bowman seismic zone occurs along a border fault of a buried Triassic basin, extending to a depth of about $6 \mathrm{~km}$ (WSRC 2000).

Underlying the Coastal Plain sediments of the central and southern portions of the SRS is a Triassic-Jurassic rift basin within the crystalline basement. This basin, called the Dunbarton Triassic basin, is located in the Aiken Plateau, about $50 \mathrm{~km}$ southeast of the Fall Line. Associated with this basin on the SRS are at least two faults; the northern border fault and a parallel fault, the Pen Branch fault, which may coincide with the border fault. These faults do not extend upward into post-Oligocene sediments at the SRS.

Faulting has also been recognized in sediments as young as Oligocene in the Atlantic Coastal Plain sediments of South Carolina. Faulting has been postulated to occur in these sediments based on structure-contour mapping of the Eocene-Oligocene unconformity, which lies between 30 and $61 \mathrm{~m}$ below the surface, in the vicinity of Charleston, and about $100 \mathrm{~km}$ from the SRS. A shallow fault, associated with a $16-\mathrm{km}$ wide graben of Oligocene and Miocene rocks which crosses beneath the Savannah River from Georgia into South Carolina, is postulated about $56 \mathrm{~km}$ southeast of the SRS. It is not currently possible to relate these shallow faults to modern earthquakes that occur at depths greater than about $2 \mathrm{~km}$.

\section{Intensities of Historical Earthquakes}

The largest known earthquake to affect the site region was the Charleston earthquake of 1886 . This Modified Mercalli Intensity (MMI) X earthquake struck Charleston SC, on August 31, 1886. The greatest intensity felt at the SRS has been estimated at MMI VI-VII (felt by all; everyone runs outdoors; damage negligible in buildings of good structure, but considerable in poorly built structures) as a result of the Charleston earthquake. Minor tremors from aftershocks of the 1886 
Charleston event were also felt in the area where the SRS is now located. Intensities of these tremors were estimated to be equal to or less than MMI IV.

Seismic activity producing earthquakes of estimated MMI up to V to VII has been present in the Bowman area (about $95 \mathrm{~km}$ northeast of the SRS) over the last 200 years. These earthquakes produced acceleration at the SRS of less than 0.1 times the earth's gravitational acceleration. An earthquake (MMI VIII) that struck Union County, SC, about $160 \mathrm{~km}$ north-northeast of the SRS in 1913 was felt at Aiken (6 km north-northwest of the SRS) with an MMI of II-III (vibration indoors like a passing truck).

Two earthquakes of MMI III or less have occurred with epicentral locations within the boundaries of the SRS. An MMI III earthquake occurred in June 1985 at the SRS, as did an MMI I-II earthquake in August 1988. Neither of the earthquakes triggered the seismic alarms at the SRS facilities, which are triggered when ground accelerations equal or exceed 0.002 times the earth's gravitational acceleration. The epicenters of these earthquakes appear to be located within about six miles of the intersection of a northwest-trending fault and the northeast-trending border fault at the northern edge of the Dunbarton Triassic basin and are relatively shallow (1 to $3 \mathrm{~km}$ below the earth's surface).

\section{Projected Recurrence of Earthquakes}

The recurrence interval for a Charleston-size shock (MMI X) for the Charleston area and for the Coastal Plain is on the order of 1,000 years, at the 95 percent confidence level. A recurrence of the 1886 Charleston earthquake would result in an intensity of MMI VII at the SRS. Recurrence of earthquakes associated with other known seismic zones in the region are not expected to be of greater intensity nor cause greater shaking at the SRS (WSRC 2000).

\section{$\underline{3.1 .5} \quad \underline{\text { Hydrology }}$}

\subsubsection{Surface Water}

The Savannah River cuts a broad valley approximately $76 \mathrm{~m}$ deep through the Aiken Plateau, on which most of the SRS sits. The Savannah River Swamp lies in the floodplain along the Savannah River and averages about $2.4 \mathrm{~km}$ wide. Upper Three Runs, Fourmile Branch, Tinker Creek, Pen Branch, Steel Creek, and Lower Three Runs are the major tributaries of the Savannah River that occur on the SRS. Three breaches of the natural levee occur at the confluences of the Savannah River with Beaver Dam Creek, Fourmile Branch, and Steel Creek, allowing discharge of these streams to the river. During swamp flooding, water from Beaver Dam Creek and Fourmile Branch flows through the swamp that parallels the river and combines with the Pen Branch flow. Pen Branch joins Steel Creek about $0.8 \mathrm{~km}$ above its mouth.

Surface water is held in artificial impoundments and natural wetlands on the Aiken Plateau. Par Pond, the largest impoundment on the SRS, is located in the eastern part of the SRS, covering about $11 \mathrm{~km}^{2}$. A second impoundment, L Lake, lies in the southern portion of SRS and covers approximately $4 \mathrm{~km}^{2}$. The waters drain from Par Pond and L Lake to the south via Lower Three Runs and Steel Creek, respectively, into the Savannah River. Lowland and upland marshes and natural and man-made basins on the SRS retain water intermittently.

Near the SRS, the flow of the Savannah River has been stabilized by the construction of upstream reservoirs. The yearly average flow is approximately $300 \mathrm{~m}^{3} / \mathrm{s}(10,400$ cubic feet per second [cfs]) at the point where Highway 301 crosses the river (approximately $20 \mathrm{~km}$ downstream of the 
site). Based on data collected from 1954 to 1.988, the minimum average annual flow rate at this location was $150 \mathrm{~m}^{3} / \mathrm{s}(5,200 \mathrm{cfs})$ in 1988 . From the SRS, river water usually reaches the coast in five to six days but may take as few as three days. At the Beaufort-Jasper water treatment plant, approximately $160 \mathrm{~km}$ downstream of the site, the average annual flow rate is estimated to be approximately $450 \mathrm{~m}^{3} / \mathrm{s}(15,800 \mathrm{cfs})$.

The watershed of Upper Three Runs drains about $500 \mathrm{~km}^{2}$ of the Upper Coastal Plain northeast of the Savannah River. Significant tributaries to this creek are Tinker Creek, which is a headwaters branch that comes in northeast of E Area, and Tims Branch, which connects up west of E Area. There are no lakes or flow control structures on Upper Three Runs or its tributaries. The stream channel has a low gradient and is meandering. Its floodplain ranges in width from 0.4 to $1.6 \mathrm{~km}$ and is heavily forested with hardwoods.

Upper Three Runs is gauged by the U. S. Geological Survey about $14 \mathrm{~km}$ above the confluence with the Savannah River, just above Road C. This location is of interest in this analysis because it is just west of $\mathrm{E}$ Area and thus is a point through which radionuclides potentially discharged to Upper Three Runs and tributaries in E Area would pass. The average annual flow at this location, as measured by the U.S. Geological Survey between 1989 and 1992 , was approximately $6.2 \mathrm{~m} / \mathrm{s}$ $(220 \mathrm{cfs})$. During the driest of the four years of measurement, the average flow was $4.8 \mathrm{~m}^{3} / \mathrm{s}(170$ cfs). These flow rates reflect contributions of upstream tributaries, including McQueen Branch and others that receive groundwater discharges from E Area. All of the major streams at SRS, including Upper Three Runs and Fourmile Branch, receive groundwater discharge and are gaining streams.

Fourmile Branch has been gauged in the vicinity of $\mathrm{E}$ Area, approximately $10 \mathrm{~km}$ from its confluence with the Savannah River. Data were collected at this gauging station for approximately four years (1985 through 1988). These data indicate an average annual flow of $0.40 \mathrm{~m}^{3} / \mathrm{s}(14 \mathrm{cfs})$ at this location. A minimum annual flow rate during the gauging period of approximately $0.34 \mathrm{~m}^{3} / \mathrm{s}$ (12 cfs) was measured in 1988 (WSRC 2000).

\subsubsection{Groundwater}

A discussion of groundwater hydrology must consider all the aquifers and confining units that affect the subsurface distribution of contaminants potentially released from the E-Area LLWF. In this report, the discussion of groundwater hydrology is restricted to hydrostratigraphic units above the Meyers Branch confining system because units below that system are considered protected from contamination. Justification for this assumption is given in the subsection entitled "Meyers Branch Confining System" below.

The nomenclature used in this report to identify hydrostratigraphic units is consistent with Aadland et al. (1995). Two different alphanumeric systems of hydrostratigraphic nomenclature were utilized in the Z- and original E-Area Performance Assessments. These systems are listed in Table 3.1-3, along with the present nomenclature. The "common" names listed in this table are names that have historically been used for the hydrostratigraphic units and that are utilized in many older documents on this subject. These units, and their hydrologic properties, are defined and described below.

Potentiometric surfaces and particle tracking data provided in the discussion of flow modeling in Section 4.3.3 of the PA support this interpretation of E-Area hydrology (WSRC 2000). 
Table 3.1-3 Hydrostratigraphic Nomenclature

\begin{tabular}{llll}
\hline $\begin{array}{c}\text { Nomenclature of Aadland et al. } \\
1995\end{array}$ & E-Area Nomenclature & $\begin{array}{c}\text { Z-Area } \\
\text { Nomenclature }\end{array}$ & $\begin{array}{c}\text { Common } \\
\text { Nomenclature }\end{array}$ \\
\hline $\begin{array}{clll}\text { Floridan Aquifer System } \\
\begin{array}{c}\text { Upper Three Runs aquifer } \\
\text { "upper" zone } \\
\text { "tan clay" zone }\end{array}\end{array}$ & Aquifer System II & & \\
"lower" zone & Aquifer unit IIB, zone 2 & Zone 7c/8 & Water table unit \\
Confining unit IIB -IIB $_{2}$ & Zone 7b & Tan clay \\
$\begin{array}{l}\text { Gordon confining unit } \\
\text { Gordon aquifer }\end{array}$ & Aquifer unit IIB, zone 1 & Zone 6/7a & Barnwell/McBean \\
& Confining unit IIA-IIB & Zone 5b & Green clay \\
Meyers Branch Confining System & Confining System I-II & Zone 4 & Congaree \\
\hline & & & Ellenton clays \\
\hline $\begin{array}{l}\text { SOURCE: } \\
\text { WSRC 2000 }\end{array}$ & & & \\
\hline
\end{tabular}




\section{Meyers Branch Confining System}

The Meyers Branch confining system overlies the Dublin and Dublin-Midville aquifer systems. Sediments of this Late Cretaceous-Paleocene system correspond to the lignitic clays and interbedded sands of the upper Steel Creek Formation and the laminated clays and shale of the Lang Syne/Sawdust Landing and Snapp Formations. At the SRS, the Meyers Branch system consists of a single hydrostratigraphic unit, the Crouch Branch confining unit, which includes several thick and relatively continuous (over several miles) clay beds. East of E Area, the Meyers Branch confining system is $41 \mathrm{~m}$ thick, $21 \mathrm{~m}$ of which are clay beds. The Crouch Branch confining unit constitutes the Meyers Branch confining system over much of the SRS, ranging in thickness from $17 \mathrm{~m}$ to $56 \mathrm{~m}$. The updip limit of the Meyers Branch confining system, where the system is no longer a regional confining system, occurs north of the intersection of McQueen Branch and Upper Three Runs streams and runs approximately east to west. North of the updip limit, the Crouch Branch confining unit continues and is considered part of the Floridan-Midville aquifer system (in which all aquifer units above and including the McQueen Branch aquifer are considered layered parts of one aquifer systemi).

Areas of the SRS which are adjacent to the Savannah River flood plain and the Upper Three Runs drainage systems, including E-Area, exhibit an "upward" gradient across the Crouch Branch confining unit. Hydraulic heads in the underlying Crouch Branch aquifer are higher than those in the overlying Gordon aquifer in these areas, due to the incisement of the overlying aquifer by these two river systems. This area of upward gradient encompasses all of E Area. The magnitude of the upward gradient is about 5 meters in the vicinity of $\mathrm{E}$ Area, but the low transmissivity of the Meyers Branch Confining System results in a low water flux into the Gordon Aquifer. Thus, in $\mathrm{E}$ Area, the confining nature of the Crouch Branch confining unit along with the head-reversal phenomenon, provides a natural protection of aquifers beneath the Floridan aquifer system from contamination.

\section{Floridan Aquifer System}

Because of relative hydrologic isolation due to the Meyers Branch confining system, only the Floridan aquifer system is of interest in the performance assessment and special analysis of potential groundwater contamination from operations at E Area. The Floridan aquifer system is comprised of the lowermost Gordon aquifer unit, the Gordon confining unit, and the uppermost Upper Three Runs aquifer unit, which contains the water table.

Gordon Aquifer Unit The Gordon aquifer unit overlies the Crouch Branch confining system and is approximately $23 \mathrm{~m}$ thick at $\mathrm{E}$ Area. The aquifer consists of sandy parts of the Late PaleoceneEarly Eocene Snapp, Fourmile, and Congaree Formations. Sands and clayey sands of the Gordon aquifer unit are largely yellow to orange in color and consist of fine- to coarse-grained, subangular to subrounded quartz. The sands range from well to poorly sorted. Locally-confining clay beds are present, as are pebbly zones. The unit dips at 1.5 to $1.7 \mathrm{~m} / \mathrm{km}$ to the south and southeast and thickens in the western portion of $E$ Area and to a minor extent to the southeast (WSRC 2000).

The hydraulic gradient in the Gordon aquifer across the SRS is generally from northeast to southwest, averaging $0.9 \mathrm{~m} / \mathrm{km}$, towards the Savannah River. However, the potentiometric surface (Aadland et al. 1995) indicates considerable deflection of the contours due to incisement of aquifer sediments by Upper Three Runs, such that flow from E Area is westerly. Potentiometric surfaces demonstrating this trend are provided in Section 4.3 .3 of the PA 
(WSRC 2000). Based on measurements and modeling (Aadland et al. 1995), an average horizontal hydraulic conductivity of $1 \times 10^{-2} \mathrm{~m} / \mathrm{s}$ is reported for this unit.

Gordon Confining Unit The Gordon confining unit separates the underlying Gordon aquifer unit from the Upper Three Runs aquifer unit. This confining unit is informally known as the "green clay." It is comprised of the fine-grained glauconitic sand and clay beds of the Middle Eocene Warley Hill Formation and the micritic limestone of the Tinker/Santee Formation. Thickness of the Gordon confining unit in the vicinity of the SRS varies from 1.5 to $25 \mathrm{~m}$. In the vicinity of $\mathrm{E}$ Area, it is from 0.6 to $9 \mathrm{~m}$ thick. Recent studies indicate the unit is composed of several lenses of green and gray clay that thicken, thin, and pinch out abruptly. Extensive carbonate sediments associated with areas of thin or truncated clay beds are present in E Area.

Leakance coefficients, estimated from modeling and pump tests, indicate an updip limit of the Gordon confining unit at the SRS that runs southwest to northeast along Upper Three Runs and Tinker Creek. Southeast of this limit, leakances are relatively low except in areas associated with extensive faulting. Laboratory- and model-derived vertical hydraulic conductivities in E Area are on the order of $5 \times 10^{-10} \mathrm{~m} / \mathrm{s}$ (Aadland et al. 1995), suggesting that the Gordon confining unit is an effective aquitard in this region. Horizontal hydraulic conductivities ranging from $1.4 \times 10^{-10}$ to $1.6 \times 10^{-9} \mathrm{~m} / \mathrm{s}$ have been determined from laboratory tests. A map of hydraulic head differences across the Gordon confining unit (Aadland et al. 1995) shows a downward gradient in the vicinity of Upper Three Runs and the Savannah River.

Upper Three Runs Aquifer Unit The Upper Three Runs aquifer unit overlies the Gordon confining unit and is the water table unit. This unit includes the sandy sediments of the Tinker/Santee Formation and all the heterogeneous sediments in the Late Eocene Barnwell Group. In the center of the SRS, the aquifer unit is $40 \mathrm{~m}$ thick. In $\mathrm{E}$ Area, the aquifer unit is divided into three hydrostratigraphic zones with respect to hydraulic properties (Aadland et al. 1995): a "lower" zone, a "tan clay" locally-confining zone, and an "upper" aquifer zone (the water table zone).

In E Area, the "lower" aquifer zone occurs between the overlying "tan clay" confining zone and the Gordon confining unit. It consists of sand, clayey sand, and calcareous sand of the Tinker/Santee Formation and of the lower part of the Dry Branch Formation. Groundwater that leaks across the "tan clay" confining zone recharges this zone. Most of the recharge water moves laterally toward the bounding streams that incise this zone; the remainder flows vertically downward across the Gordon confining unit. Hydraulic conductivity of the "lower" zone has been estimated for the E-Area vicinity by several methods: slug tests, pumping tests, minipermeameter test, and sieve analyses. Average values for the various methods range from $3 \times 10^{-6} \mathrm{~m} / \mathrm{s}$ to $6 \times$ $10^{-4} \mathrm{~m} / \mathrm{s}$. The lower values are based on pumping tests, and the higher values are based on sieve analyses. The large discrepancy between the two methods suggests that large-scale heterogeneities, not sample-in-sieve-analysis techniques, are important in determining conductivity.

The "tan clay" confining zone is a leaky confining zone, ranging in thickness from 0 to $10 \mathrm{~m}$ throughout the E-Area vicinity. The average thickness is about $3 \mathrm{~m}$. The clay beds of this confining zone, when present, generally support a head difference (up to $5 \mathrm{~m}$ ) in E Area between the "upper" and "lower" aquifer zones of the Upper Three Runs aquifer unit and thus retard the movement of water downward across this zone. Laboratory analyses of undisturbed samples of the "tan clay" confining zone yielded a range of hydraulic conductivities from $6 \times 10^{-11}$ to $5 \times 10^{-7}$ $\mathrm{m} / \mathrm{s}$ in the horizontal direction and $1 \times 10^{-11}$ to $4 \times 10^{-7} \mathrm{~m} / \mathrm{s}$ in the vertical direction (Aadland et al. 1995). 
In E Area, the "upper" aquifer zone consists of the silty sands of the Irwinton Sand Member of the Dry Branch Formation overlain by the clayey sands of the Tobacco Road Formation. The water table occurs in the "upper" zone. This zone overlies the "tan clay" confining zone, when present, or the "lower" aquifer zone when the confining zone is absent. Units below the "upper" aquifer zone are always saturated, so the "upper" aquifer is not a perched system. Slug tests, minipermeameter tests, pumping tests, and sieve analyses have been used to estimate hydraulic conductivity of the "upper" zone in the vicinity of E Area (Aadland et al. 1995). The average hydraulic conductivity estimates for the "upper" aquifer zone ranged from $2 \times 10^{-6}$ to $5 \times 10^{-4} \mathrm{~m} / \mathrm{s}$ for the various methods.

Three streams on site, Upper Three Runs to the north of E Area, McQueen Branch (a tributary of Upper Three Runs) to the northeast, and Fourmile Branch to the south, are natural boundaries to groundwater flow in the Upper Three Runs aquifer unit. All creeks cut into this, and thus groundwater is either intercepted by the creeks or recharges the underlying Gordon aquifer unit. A groundwater divide occurs in this water table unit due to the influence of these streams.

\section{Hydrologic Characteristics of the Vadose Zone}

The vadose zone extends from the ground surface downward to the water table. Hydraulic characteristics of unsaturated soil in E Area were most recently investigated by Core Laboratories, Inc., in Carollton, Texas (WSRC 2000). Capillary pressure vs. water saturation relationships and relative permeability vs. water saturation relationships were developed for field samples of topsoil, gravel, two clays, sand, and backfill to provide a range of analyses for various vadose zone materials found, or planned for use, in the E-Area LLWF. Saturated hydraulic conductivity of topsoils was measured to be on the order of $10^{-5} \mathrm{~m} / \mathrm{s}$, with porosity on the order of 0.40 . Saturated hydraulic conductivity of gravels and clays were measured to be on the order of $10^{-1}$ and $10^{-8} \mathrm{~m} / \mathrm{s}$, respectively, with respective porosities of 0.38 and 0.56 .

\section{$\underline{3.1 .6} \quad \underline{\text { Geochemistry }}$}

Geochemical aspects of the disposal site are not evaluated nor used directly in assessing radionuclide migration. Rather, site-specific sorption coefficients, which are affected by $\mathrm{pH}$ and other geochemical conditions, are used when available. Geochemical modeling conducted for the E-Area PA (WSRC 2000) was restricted to the vault environment and thus is not pertinent to the present discussion of disposal site characteristics.

\subsubsection{Natural Resources}

\subsubsection{Geologic Resources}

The only material of significance as a geologic resource in the vicinity of the SRS is kaolin clay. About 90 percent of the U. S. production of kaolin at one time came from a district in Georgia and South Carolina that includes Aiken County. Commercial deposits occur as lenses in the Lang Syne Formation along the Fall Line bordering the northwestern edge of the Coastal Plain (WSRC 2000).

At E Area, the Lang Syne Formation is at a depth greater than $100 \mathrm{~m}$ from the ground surface, making commercial exploration unlikely due to the large amount of overburden that would have to be removed to exploit a deposit. 


\subsubsection{Water Resources}

The South Carolina Department of Health and Environmental Control (SCDHEC) has been delegated authority by the U.S. Environmental Protection Agency (EPA) to implement and enforce the requirements of the Clean Water Act for the State of South Carolina. SCDHEC therefore is responsible for maintaining the chemical and biological integrity of all state waters, including those on federal reservations such as SRS. It does this by enforcing a system of water quality standards and by regulating all point-source discharges through the National Pollutant Discharge Elimination System (NPDES) program. SCDHEC is the principal regulatory authority for water quality issues on the SRS.

\section{Surface Water}

The Savannah River is the principal surface water system associated with the SRS. Five of its major tributaries (Upper Three Runs, Fourmile Branch, Pen Branch, Steel Creek, and Lower Three Runs) flow through and drain the SRS. Mean annual flow at river mile 187.4, approximately 12 miles south of Augusta, GA, during the period 1984 to 1996 was $16,580 \mathrm{cfs}$. The Savannah River serves as a domestic and industrial water source for the SRS and several downstream communities (the cities of Port Wentworth and Savannah in Georgia and Beaufort and Jasper counties in South Carolina). The intakes for these downstream water systems are located at river miles 29 and 39.2, respectively. In addition, the Vogtle Electric Generating Plant, located across the river from the SRS, uses the Savannah River for cooling water, withdrawing an average of $46 \mathrm{cfs}$. Table 3.1-4 characterizes Savannah River water quality both up- and downstream of the SRS. Table 3.1-5 characterizes water quality in SRS streams (WSRC 2000).

\section{Groundwater}

Within 20 miles of the SRS, there are more than 56 major municipal, industrial, or agricultural groundwater users that consume approximately 36 million gallons of water per day. Total SRS groundwater (domestic and process water) use ranges from 9 to 12 million gallons per day. At the SRS, only the deeper aquifers (Crouch Branch and McQueen Branch) are used as groundwater sources.

Under most of the SRS, the quality of groundwater is considered to be good. The pH for SRS groundwater ranges from 4.9 to 7.7 and the water is generally soft. Concentrations of dissolved and suspended solids are low, but iron concentrations are elevated in some of the aquifers. At the SRS, approximately 5 to 10 percent of the shallow aquifer system has been contaminated with tritium, industrial solvents, metals, and other chemicals (WSRC 2000).

\subsection{Facility Characteristics}

3.2.1 Water Infiltration and Disposal Unit Cover Integrity

\subsubsection{Low-Activity Waste Vaults}

Each of the LAW Vaults will be closed in stages. Individual cells would be closed, then the entire vault area would be closed. Low-activity waste vault final closure consists of placing an earthen cover with an engineered clay cap over the entire vault area.

The closure concepts developed for the E-Area LLWF are discussed in additional detail in Section 4.0 and are illustrated in Appendix A. Closure operations will begin when an individual 
Table 3.1-4 Water Quality in the Savannah River Upstream and Downstream from SRS (Calendar Year 1996)

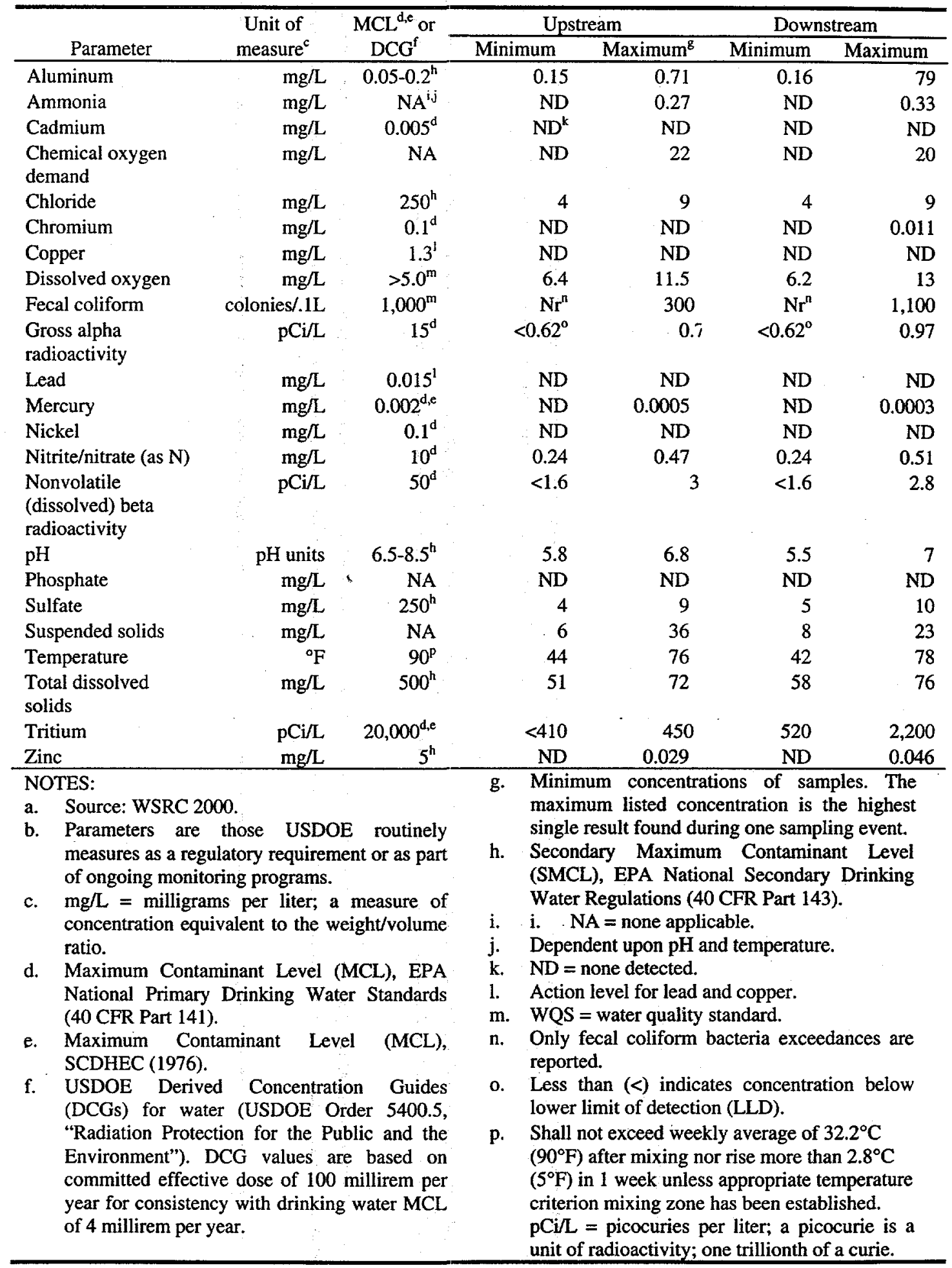


Table 3.1-5 Water Quality in Selected SRS Streams

\begin{tabular}{|c|c|c|c|c|c|c|c|}
\hline \multirow{2}{*}{$\begin{array}{l}\text { Sampling location } \\
\text { Upper Three Runs at } \\
\text { Road A (1996) }\end{array}$} & \multicolumn{2}{|c|}{ Temperature $\left({ }^{\circ} \mathrm{F}\right)$} & \multirow{2}{*}{$\begin{array}{r}\mathrm{pH} \\
6.35\end{array}$} & \multirow{2}{*}{$\begin{array}{r}\begin{array}{c}\text { Dissolved } \\
\text { oxygen } \\
(\mathrm{mg} / \mathrm{L})\end{array} \\
8.21\end{array}$} & \multirow{2}{*}{$\begin{array}{r}\begin{array}{c}\text { Specific } \\
\text { conductance } \\
(\mu \mathrm{S} / \mathrm{cm})\end{array} \\
24.3\end{array}$} & \multirow{2}{*}{$\begin{array}{r}\begin{array}{l}\text { Turbidity } \\
\text { (NTU) }\end{array} \\
13.55\end{array}$} & \multirow{2}{*}{$\begin{array}{r}\begin{array}{c}\text { Total } \\
\text { suspended } \\
\text { solids } \\
(\mathrm{mg} / \mathrm{L})\end{array} \\
13.33\end{array}$} \\
\hline & Mean & 63 & & & & & \\
\hline & Range & $45.3-74.3$ & $6-7$ & $6.5-12.7$ & $21-29$ & $3.2-65$ & $3-51$ \\
\hline \multirow{2}{*}{$\begin{array}{l}\text { Upper Three Runs at } \\
\text { Road A (1987-1991) }\end{array}$} & Mean & 66.7 & 6.08 & 8.36 & 24.5 & 5.24 & 10 \\
\hline & Range & NA & NA & $4.9-12$ & $3.0-41$ & $1.0-22$ & 2- 97 \\
\hline \multirow{2}{*}{$\begin{array}{l}\text { Upper Three Runs at } \\
\text { Road 8-1 (1996) }\end{array}$} & Mean & 61.5 & 6.03 & 8.29 & 48.2 & 5.60 & 9 \\
\hline & Range & $49.6-71.2$ & $5.3-6.8$ & $5.2-10.2$ & $3-140$ & $1.6-11$ & $2-15$ \\
\hline \multirow{2}{*}{$\begin{array}{l}\text { Crouch Branch at Road } 4 \\
\text { (1996) }\end{array}$} & Mean & 64.9 & 6.06 & 7.13 & 37.9 & 26.23 & 16 \\
\hline & Range & $46.4-76.6$ & $5.4-6.4$ & $5.2-8.5$ & $22-50$ & $3.4-130$ & $4-76$ \\
\hline \multirow{2}{*}{$\begin{array}{l}\text { Lower Three Runs at } \\
\text { Patterson Mill (1996) }\end{array}$} & Mean & 64 & 6.29 & 7.49 & 84.5 & 4.28 & 9 \\
\hline & Range & $49.3-80.6$ & $6-7$ & $5.8-10.6$ & $60-120$ & $1.2-9.8$ & $2-24$ \\
\hline \multirow{2}{*}{$\begin{array}{l}\text { Lower Three Runs at } \\
\text { Patterson Mill (1987- } \\
\text { 1991) }\end{array}$} & Mean & 64.4 & NA & 8.0 & 75 & 2.8 & 5 \\
\hline & Range & $45.9-84.2$ & $5.9-7.4$ & $5.8-11$ & $13-140$ & $0.94-38$ & $1-34$ \\
\hline $\begin{array}{l}\text { NOTES: } \\
\text { NA = Not available } \\
\text { SOURCE: } \\
\text { WSRC 2000 }\end{array}$ & & & & & & & \\
\hline
\end{tabular}


cell is filled with waste. The cell opening will be sealed with reinforced concrete. The reinforcing steel will be tied into the reinforcing steel of the vault itself, forming a unified structure. Near the end of the active disposal period of the E-Area LLWF (i.e., after most or all of the vaults and trenches have been constructed and filled and the individual cell or trenches closed), backfill will be placed around and over the disposal units.

At least $0.9 \mathrm{~m}$ of backfill will be placed around the top of the vaults. This layer will serve to establish slopes for the overlying layers so that infiltrating water will tend to flow down the slope and away from the vaults, limiting the amount of infiltration into the vaults themselves. Above this layer of backfill, a laterally extensive moisture barrier will be installed. This moisture barrier will consist of $0.76 \mathrm{~m}$ of clay and an overlying layer of $0.3 \mathrm{~m}$ of gravel. A geotextile fabric will be placed on the gravel layer, and a second backfill layer, approximately $0.76-\mathrm{m}$ thick, will be placed over the moisture barrier. Finally, a $0.15-\mathrm{m}$ layer of topsoil will be placed on the top layer of backfill. This sequence of layers provides a minimum of $2.9 \mathrm{~m}$ of cover for each vault.

Final closure of the E-Area LLWF will be accomplished by constructing a drainage system and revegetating the site. The drainage system will consist of a system of rip-rap lined ditches that intercept the gravel layer of the moisture barrier. These ditches will divert surface runoff and water intercepted by the moisture barrier away from the disposal site. The drainage ditches will be constructed between rows of vaults and around the perimeter of the E-Area LLWF.

The topsoil will be revegetated with bamboo. A study conducted by the U.S. Department of Agriculture (USDA) Soil Conservation Service has shown that these two species of bamboo (Phyllostachys bissetii and Phyllostachys rubromarginata) will quickly establish a dense ground cover which will prevent the growth of pine trees, the most deeply rooted naturally occurring plant type at SRS. Bamboo is a shallow-rooted climax species which evapotranspirates yearround in the SRS climate, thus removing a large amount of moisture from the soil and decreasing the infiltration into the underlying disposal system.

Hydraulic properties used in the PA for the various soil layers are listed in Table 3.2-1. The topsoil and upper backfill layer serve to store and distribute infiltrating water. These layers intercept incoming water and redirect a significant portion in the horizontal direction to drainage ditches installed at the E-Area LLWF. Computer simulations of flow through the cover show that the gravel drainage layer will carry away a major portion of the water that would normally infiltrate at the E-Area LLWF $(40 \mathrm{~cm} / \mathrm{yr})$. These are nominal values for key parameters of closure design. In the PA, the cover system is assumed to maintain its integrity until the underlying disposal unit fails. For the LAW Vaults failure is calculated to occur 3,100 years after closure.

\subsubsection{Intermediate-Level Vaults}

The closure concept for the IL Vaults is identical to that for the LAW Vaults (see Section 3.2.1.1). The PA assumed that the cover system would maintain its integrity until the underlying disposal unit fails. For the IL Vaults, failure is calculated to occur 1,050 years after closure.

\subsubsection{Very-Low-Activity Waste Disposal Trenches}

Final closure of the disposal trenches will be consistent with that described for the LAW Vaults (Section 3.2.1.1). Briefly, approximately $0.9 \mathrm{~m}$ of native backfill is assumed to be placed over the filled trenches (which themselves include $1.2 \mathrm{~m}$ of clean soil at the top), over which a laterally extensive moisture barrier is assumed to be placed. The moisture barrier consists of $0.76 \mathrm{~m}$ of clay overlain by $0.3 \mathrm{~m}$ of gravel and a geotextile fabric. Over this moisture barrier, $0.76 \mathrm{~m}$ of 
Table 3.2-1 Values for Hydraulic Properties of Vault Closure Design

\begin{tabular}{lcc}
\hline & Layer Description & Hydraulic \\
& Conductivity $(\mathrm{m} / \mathrm{s})$ \\
\hline & Clay & $1.0 \times 10^{-9}$ \\
& Gravel & $5.0 \times 10^{-3}$ \\
& Backfill & $1.0 \times 10^{-7}$ \\
\hline SOURCE: & & \\
WSRC 2000 & & \\
\hline
\end{tabular}


backfill is assumed, followed by $0.15 \mathrm{~m}$ of topsoil. As a result, a minimum of $2.9 \mathrm{~m}$ of cover material is assumed to overlie the disposal trenches at closure. Revegetation with bamboo and drainage ditches are assumed to constitute final closure, for the purposes of stabilizing soil, preventing pine tree growth, and diverting excess water from the gravel layer. In the PA, the cover system is assumed to maintain its integrity until the underlying disposal unit fails. For the very low activity waste trenches, failure is assumed to occur 100 years after closure.

\subsubsection{Intimately-Mixed Cement-Stabilized Waste Disposal Trenches}

The cover for these trenches containing intimately-mixed cement-stabilized waste is identical to that described in Section 3.2.1.3 for the trench disposal units. The PA assumed the cover system would maintain its integrity until the underlying disposal unit fails. For the intimately-mixed cement-stabilized waste trenches, failure is assumed to occur 300 years after closure.

\subsubsection{Cement-Stabilized Encapsulated Waste Disposal Trenches}

The cover for these trenches containing cement-stabilized encapsulated waste is also identical to that described in Section 3.2.1.3 for the trench disposal units. In the PA, the cover system is assumed to maintain its integrity until the underlying disposal unit fails. For the cement-stabilized encapsulate waste trenches, failure is assumed to occur 300 years after closure.

\subsubsection{Naval Reactor Waste Pads}

The NR waste stainless steel casks with carbon steel or low-alloy steel shipping containers containing NR components will be placed within the E-Area LLWF boundary, and therefore final closure will be similar to that for the entire facility (see Section 3.2.1.1). Briefly, 0.9-m of backfill from the Burma Road borrow pit is assumed to be placed over at-grade casks, above which a laterally extensive moisture barrier is assumed to be placed. The moisture barrier consists of 0.76 $\mathrm{m}$ of clay overlain by $0.3 \mathrm{~m}$ of gravel and a geotextile fabric. Over this moisture barrier, $0.76 \mathrm{~m}$ of backfill is assumed, followed by $0.15 \mathrm{~m}$ of topsoil. As a result, a minimum of $2.9 \mathrm{~m}$ of cover material is assumed to overlie the NR disposal casks at closure. Revegetation with bamboo and drainage ditches are assumed to constitute final closure, and are intended to stabilize soil against erosion, prevent pine tree growth, and divert excess water from the gravel layer. In the PA, the cover system is assumed to maintain its integrity until the underlying disposal unit fails. For the NR waste pads, failure is assumed to occur 750 years after closure.

Structural Stability and Inadvertent Intruder Barrier

\subsubsection{Low-Activity Waste Vaults}

The LAW Vault features that promote structural stability until roof collapse (See Section 4.1.3.1 and Appendix D of the PA [WSRC 2000]) are:

- The vaults are on-grade, reinforced concrete structures within an excavated area. The walls are structurally mated to a 30 -inch footer that is continuous under all cells in each module. The vaults have no liners attached to them. The vaults are designed to withstand Design Basis Accident loads (as specified in Project S2889) and therefore assure continued structural stability.

- Upon filling the cells with waste, the exterior access opening is sealed with cast-in-place concrete to form a continuous wall. 
The entire vault is covered with a reinforced concrete roof slab, supported on pre-cast concrete beams. The roof slab will be covered with a bonded-in-place layer of fiberboard insulation and a layer of waterproof membrane roofing. The roof slab and pre-cast beams ensure structural stability for about 3,000 years. They also provide a barrier to intrusion for this time period because normal residential construction and well drilling equipment used in the vicinity of the SRS is not capable of penetrating the roof structure.

The final closure for the LAW Vaults consists of placing an earthen cover with an engineered clay cap over the entire LAW Vault area. Voids are present on the cells of the LAW Vaults during and after filling. Approximately 50 percent of the vault volume is void space. However, these voids do not impact the structural stability of the LAW Vaults until the walls and roof weaken to the point of collapse.

The potential for increased infiltration due to subsidence at the time of roof collapse is addressed in the PA in Section 5.4 (WSRC 2000). This shows that increasing infiltration by a factor of three causes an increase in amount of a radionuclide released ranging from 0 to 2.6 times.

\subsubsection{Intermediate-Level Vaults}

The IL Vault features that promote structural stability are:

- The vaults are below-grade reinforced concrete structures. All walls are structurally mated to $21 / 2$-foot thick concrete slabs that extend approximately 2 feet beyond the outside of the exterior walls. The vaults are designed to withstand loads imposed by Design Basis Accidents (as specified in Project S2889) and therefore assure continued structural stability.

- Waste is containerized in engineered metal containers before being brought to the vault. The containers are stacked in layers. After a layer of waste containers is placed in a cell, grout will be poured to encapsulate the containers and form a surface for emplacement of the next layer of containers.

- After being filled with waste and layers of grout, the vault will be covered with a top layer of grout. A thick (thickness varies from 2-feet-3 inches to 3-feet-2 inches) reinforced concrete roof slab will completely cover all nine cells of the IL Vault. The roof slab will extend over and around the cell-wall stubs and will be covered with a bondedin-place layer of fiberboard insulation and layer of waterproof membrane roofing. Structural stability of the IL Vault roof is expected for about 1,050 year. The roof and grout layer provide a barrier to both water infiltration and intrusion before this time period.

The Intermediate-Level Tritium (ILT) portion has two cells, one of which will dispose of tritium crucibles in silos. The silo system consists of vertical cylinders that are grouted in place, thus providing stabilization and shielding.

\subsubsection{Very-Low-Activity Waste Disposal Trenches}

The disposal trenches do not have features that provide structural stability. The closure system is assumed to fail at the end of the institutional control period, 100 years after closure. 
Voids may occur when readily degradable materials, such as wood products, are reduced in volume by natural processes. Subsidence in the trenches may occur at this time, which is likely to occur within the period of active institutional control (i.e., within 100 years after closure). It is assumed in the PA that damage to the cover system due to subsidence will be repaired during this time. A sensitivity analysis was also conducted to evaluate the effect of increased infiltration due to subsidence on disposal trench performance. This analysis indicated that the effects on flux of tripling the infiltration ranged from almost no effect for certain radionuclides to an increase of approximately two times for other radionuclides.

Intimately-Mixed Cement-Stabilized Waste Disposal Trenches

The intimately-mixed cement-stabilized wasteform is likely to maintain its structural stability and minimize the occurrence of voids for 300 years, thus limiting infiltration of water through and prohibiting human intrusion into the waste. The cover system described in Section 3.2.1.3, while intact, will also limit water infiltration.

\subsubsection{Cement-Stabilized Encapsulated Waste Disposal Trenches}

The cement-stabilized encapsulated wasteform is likely to maintain its structural stability for 300 years, thus limiting infiltration of water through and prohibiting human intrusion into the waste. The cover system described in Section 3.2.1.3, while intact, will also limit water infiltration.

\subsubsection{Naval Reactor Waste Pads}

Strength requirements of the NR waste containers are such that they must remain intact while transporting NR components, which have a density of $7,700-8,000 \mathrm{~kg} / \mathrm{m}^{3}\left(480-500 \mathrm{lbs} / \mathrm{ft}^{3}\right)$. Thus it is expected that these containers will maintain structural stability for 10,000 years. The gasketed containers are also designed to deter water infiltration for at least the 750 years estimated in the PA.

\subsection{Waste Characteristics}

Low-level radioactive solid waste may be characterized and segregated into three categories. The disposition of waste containers in the E-Area LLWF will be based on these categories. The waste categories are as follows:

1) Low-activity waste

2) Intermediate-level waste

3) Naval Reactor components.

Low-activity waste and intermediate-level waste will be disposed of in the designated vaults; trenches will take soil, rubble, wood and job control waste, and concrete waste forms (intimatelymixed cement-stabilized waste and cement-stabilized encapsulated waste); and NR components will be disposed of in the pad in the E-Area LLWF.

Estimated radionuclide inventories for each of the disposal units are provided in the PA. For those disposal units that have an operational history (i.e., LAW Vault, IL Vault, and slit trenches), the actual inventory as of 6/1/98 was used to develop a concentration value for each radionuclide; the concentrations were then applied to the forecasted waste volume to estimate the forecasted 
inventory. For the NR pad, the projected inventory was derived from forecasted waste volumes provided by USDOE-NR. For the intimately-mixed cement-stabilized waste, projections of the volume of waste to be processed through the Consolidated Incinerator and radionuclide inventory data on those waste types from waste emplaced in the LAW Vault were used to develop the projected inventory for five of these trenches. The inventory for the cement-stabilized encapsulated waste was derived from information available on currently stored equipment that will be considered for such disposal.

\subsubsection{Low-Activity Waste Vaults}

\subsubsection{Waste Type/ Chemical and Physical Form}

The LAW will include job control waste, scrap metal, and contaminated soil and rubble. Job control waste will consist of potentially contaminated protective clothing including plastic suits, shoe covers, lab coats, and plastic sheeting. Scrap metal will be contaminated tools, process equipment, and laboratory equipment. Soil and rubble will be generated from demolition and cleanup activities. Historically, the majority of this waste has been generated by the High-Level Waste (HLW) tank farms.

The radioactive content of LAW is primarily fission products from the tank farms and Separations. Waste contaminated with uranium will be received from M Area. Waste will also be received from offsite facilities, which will have a variety of radionuclides.

\subsubsection{Radionuclide Inventory}

The radiation dose rate measured at $5 \mathrm{~cm}$ from the surface of an unshielded container is less than $200 \mathrm{mR} / \mathrm{hr}$ for containers destined for the E-Area LLWF (LAW Vault). The transuranic activity concentration for the LAW Vault is less than $100 \mathrm{nCi} / \mathrm{g}$ of alpha activity.

The 20-year projected inventory for the two LAW Vaults planned for the E-Area LLWF is provided in the PA.

\subsubsection{Waste Volume}

The LAW Vault provides approximately $4.8 \times 10^{4} \mathrm{~m}^{3}$ of LAW capacity. Provided that curie inventory limits are not exceeded, waste volumes may approach that capacity for both LAW Vaults during the period of operation of these units.

\subsubsection{Packaging Criteria}

All LLW is subject to the packaging requirements of the 1S Manual. Most of the LAW will be received in standard $1.2 \times 1.2 \times 1.8 \mathrm{~m}$ metal containers (B25 boxes), but some waste will also be received in standard $0.6 \times 1.2 \times 1.8 \mathrm{~m}$ containers (B12 boxes) or $210-\mathrm{L}$ drums. The LAW may also be received in non-standard engineered concrete or metal containers. These containers shall be pre-approved by Solid Waste Management prior to their receipt at the E-Area LLWF.

Many different containers will be received at the E-Area LLWF. However, all containers are required by the Technical Safety Requirements (TSRs) to be engineered concrete or metal containers that have been approved by Solid Waste. A procedure has been written that defines this approval process and requires Solid Waste Management Engineering, Solid Waste Management Operations, and Solid Waste Management Maintenance to concur that the container 
can be safely handled, will not impair vault space utilization, and will satisfactorily contain the waste contents.

The B25 and B12 containers are carbon steel boxes that have been used in the past for waste disposal in the Solid Waste Disposal Facility (SWDF). The boxes are similar in construction with the exception of size. The B25 is a $2.5 \mathrm{~m}^{3}$ container that is approximately $1.2 \mathrm{~m}$ high, $1.2 \mathrm{~m}$ wide, and $1.8 \mathrm{~m}$ long. It is typically constructed of 14-gauge carbon steel $(1.9 \mathrm{~mm})$ but some B25s are constructed of 12-gauge carbon steel $(2.6 \mathrm{~mm})$ to allow use in the compactor. The B12 is a $1.3 \mathrm{~m}^{3}$ container that is approximately $0.6 \mathrm{~m}$ high, $1.2 \mathrm{~m}$ wide, and $1.8 \mathrm{~m}$ long and is typically constructed of 12-gauge carbon steel.

The B12 and B25 containers are constructed with a rubber-gasket seal between the lid and the container with a gasket compression of 20 to 30 percent. The interior and exterior of each container is coated with a zinc chromate primer. The exteriors are given an additional coating of alkyd enamel and a finish coat of paint.

A variety of drums, corresponding to international drum specifications, will also be received as standard containers. Use of these containers is restricted to situations where use of a B25 is not practical. Drums will be banded together and banded to a fire-resistant pallet prior to shipment to the E-Area LLWF.

For waste that cannot be placed in a standard container, specific size and weight limits have been specified. Maximum dimensions for containers in the LAW Vaults are $4.3 \mathrm{~m}$ high $\times 7.3 \mathrm{~m}$ wide $\times$ $15.2 \mathrm{~m}$ long. The maximum dimensions for containers in the IL Vaults are $7.3 \mathrm{~m}$ high $\times 10.7 \mathrm{~m}$ long $\times 6.1 \mathrm{~m}$ wide. The maximum uniform load on the vault floor cannot exceed $4.9 \times 10^{6} \mathrm{~kg} / \mathrm{m}^{2}$ for the IL Vaults and $2.8 \times 10^{6} \mathrm{~kg} / \mathrm{m}^{2}$ for the LAW Vaults.

\subsubsection{Pre-Disposal Treatment Methods}

Many LAW containers, upon receipt at the E-Area LLWF, are opened, and the contents are sorted at the sorting and segregation facility. The compactible fraction is compressed in a supercompactor prior to disposal.

\subsubsection{Waste Acceptance Restrictions}

Waste acceptance for disposal in the LAW Vaults must conform to criteria put forth in the SRS Waste Acceptance Criteria (WAC) [WSRC 1999].

\subsection{2 $\quad$ Intermediate-Level Vaults}

\subsubsection{Waste Type/ Chemical and Physical Form}

The IL Vault will be used for disposal of IL waste. Intermediate-level waste consists of job control waste, scrap hardware, and contaminated soil and rubble. Job control waste is primarily highly contaminated lab coats, plastic suits, shoe covers, plastic sheeting, etc. This material is assumed to be combustible and is contaminated primarily with fission products. Scrap hardware consists of reactor hardware, reactor fuel fittings and target fittings, jumpers, and used canyon and tank farm equipment contaminated with fission products and/or induced activity. 
All of the IL waste will be packaged in engineered metal or concrete containers that have been approved by Solid Waste Management. The containers will be remotely placed into the vault in layers. IL waste containers will be grouted in place to provide better waste isolation, reduce dose to operators, and improve stacking of additional containers.

Tritiated waste will be disposed in the ILT portion of the IL Vault. This portion consists of two cells, one for each of the two subcategories of tritiated waste. Tritium crucibles will be disposed of in the first cell. This wasteform is generated by the tritium facilities in the process used to recover tritium from target assemblies. The crucibles will be over-packed into a stainless-steel container that is about $0.5 \mathrm{~m}$ in diameter and $6.1 \mathrm{~m}$ in length. The crucible cell is specially designed with vertical silos to receive waste. All other tritiated waste will be disposed of in the bulk tritiated waste cell. This waste will consist of job control waste and used process equipment that is contaminated with tritium. Bulk tritiated waste will be disposed of in engineered metal or concrete containers.

Depending on the origin of this waste, it can contain either fission products or induced activity contamination. The induced activity waste will be mostly metal reactor hardware and fittings that have been exposed to a high neutron field. This waste generates a high radiation field but the activity is fairly immobile due to the metal matrix. Job control waste and process piping from Separations and High Level Waste Management will be contaminated with fission products. These fission products will be both loose and fixed surface contamination.

\subsubsection{2}

Radionuclide Inventory

Waste is categorized as IL if the radiation dose rate measured at $5 \mathrm{~cm}$ from the surface of the unshielded container is greater than $200 \mathrm{mR} / \mathrm{hr}$. Also, the transuranium element alpha activity concentration is less than $100 \mathrm{nCi} / \mathrm{g}$.

The 20-year projected inventory for the two IL Vaults planned for the E-Area LLWF is provided in the PA.

\subsubsection{Waste Volume}

The IL Vault provides approximately $5.7 \times 10^{3} \mathrm{~m}^{3}$ of waste capacity for Intermediate-Level NonTritium (ILNT) waste and $1.6 \times 10^{3} \mathrm{~m}^{3}$ for ILT waste. Provided that curie inventory limits are not exceeded, waste volumes may approach that capacity for both IL Vaults during the period of operation of these units.

\subsubsection{Packaging Criteria}

The bulk of the waste received by the E-Area LLWF is containerized by the waste generator in B25 or B-12 engineered metal boxes, or in 55-gallon drums. Tritium crucibles will be packaged in a stainless steel overpack container. The overpack will be an $0.46-\mathrm{m}$ diameter pipe which is approximately $6.1 \mathrm{~m}$ long. The lid will be sealed to the overpack with a compression O-ring. The O-ring will not prevent off-gassing of tritium in the IL Tritium Vault crucible silos. The IL Tritium Vault is designed to receive 142 of these tritium crucible overpacks. 


\subsubsection{Pre-Disposal Treatment Methods}

No pre-disposal treatment methods are currently planned for IL waste.

\subsubsection{Waste Acceptance Restrictions}

Waste acceptance for disposal in the IL Vaults must conform to criteria put forth in the SRS WAC (WSRC 1999).

\subsubsection{Very-Low-Activity Waste Disposal Trenches}

3.3.3.1 Waste Type/ Chemical and Physical Form

Waste destined for trench disposal can generally be described as contaminated soil, rubble, concrete, wood debris and job control waste. Levels of radioactivity are lower than for waste destined for vault disposal.

\subsubsection{Radionuclide Inventory}

The 20-year projected inventory for ten trenches planned for the E-Area LLWF is provided in the PA.

\subsubsection{Waste Volume}

The volume capacity of each trench is $5760 \mathrm{~m}^{3}$. Therefore the capacity of ten trenches is $5.7 \times 10^{4}$ $\mathrm{m}^{3}$.

\subsubsection{Packaging Criteria}

No packaging criteria apply to the waste destined for very-low activity trench disposal.

\subsubsection{Pre-Disposal Treatment Methods}

Containerized waste will be considered for pretreatment in the sorting and segregation facility (see Section 3.3.1.5). This may include supercompaction of a portion of the waste.

\subsubsection{Waste Acceptance Restrictions}

Waste acceptance for disposal in trenches must conform to criteria put forth in the SRS WAC (WSRC 1999).

\subsubsection{Intimately-Mixed Cement-Stabilized Waste Disposal Trenches}

The Savannah River Site is planning the direct trench disposal of cement-solidified wasteforms. These wasteforms will be produced by blending solid or liquid waste products with cement or by encapsulating a solid form within a cement product, forming a solid waste form with physical and chemical stability. The nature of the waste form and the very low levels of radioactivity expected in the waste make trench disposal a cost-effective alternative to emplacement in the E-Area Vaults. 


\subsubsection{Waste Type/Chemical and Physical Form}

The Consolidated Incinerator Facility (CIF) is designed to treat hazardous, mixed, and low-level radioactive waste by destroying organic compounds and reducing the volume of contaminated combustible materials. The air pollution control system for the CIF employs a water quench and steam atomized scrubber which collect salt, ash and trace metals in the liquid they use. To minimize waste, scrubber condensate will be used as make-up water in the quench. Water is recirculated in the quench until a predetermined amount of suspended solids or dissolved salts are present. This liquid, called blowdown, will be pumped to storage tanks prior to treatment and disposal. Both blowdown and the ash residual from the incineration process constitute the waste destined for the intimately-mixed cement-stabilized waste trenches. Physical characteristics of the cementitious wasteform are discussed in Section 3.3.4.5.

\subsubsection{Radionuclide Inventory}

The 20-year projected inventory for the intimately-mixed cement-stabilized waste planned for disposal in ten E-Area LLWF trenches is provided in the PA.

\subsubsection{Waste Volume}

The volume capacity of each trench is $5760 \mathrm{~m}^{3}$. Therefore the capacity of ten trenches is $5.7 \times 10^{4}$ $\mathrm{m}^{3}$.

\subsubsection{Packaging Criteria}

The cementitious wasteform will be solidified in 55-gallon carbon steel drums. No other packaging criteria have been specified at this time.

\subsubsection{Pre-Disposal Treatment Methods}

The ash residual from the incineration process and potentially some of the blowdown waste will be stabilized with Portland cement in the ashcrete processor, which produces drums of solidified waste. Extensive studies have been carried out to optimize stabilization of both the ash and blowdown and to produce acceptable wasteforms.

Tests to determine the permeability of the cementitious wasteform were conducted at the University of South Carolina. Three wasteform samples were used with the results varying from $3.0 \times 10^{-11} \mathrm{~m} / \mathrm{s}$ to $7.3 \times 10^{-14} \mathrm{~m} / \mathrm{s}$ which is well within the assumption in the PA.

Results of tests of the compressive strength of this wasteform have varied from 1571 to $5220 \mathrm{psi}$, all of which are much higher that the 500 psi recommendation by the Nuclear Regulatory Commission (NRC).

\subsubsection{Waste Acceptance Restrictions}

Waste acceptance for disposal in the trenches designated to receive intimately-mixed cementstabilized waste must conform to criteria put forth in the SRS WAC. 


\section{$\underline{3.3 .5}$} Disposal Trenches for Cement-Stabilized Encapsulated Waste

\subsubsection{1}

Waste Type/Chemical and Physical Form

In general, large equipment contaminated with radioactive materials will constitute the type of waste destined for disposal in these trenches. Any solid wasteform, however, that meets the WAC, which is based on the results of the PA, will be suitable for disposal as an encapsulated wasteform.

\subsubsection{Radionuclide Inventory}

The 20-year projected inventory for the cement-stabilized encapsulated waste planned for disposal in ten E-Area LLWF trenches is provided in the PA.

\subsubsection{Waste Volume}

The volume capacity of each trench is $5760 \mathrm{~m}^{3}$. Therefore the capacity of ten trenches is $5.7 \times$ $10^{4} \mathrm{~m}^{3}$.

\subsubsection{Packaging Criteria}

Wasteforms encapsulated in grout will be placed directly in the designated trenches. No packaging criteria apply to waste destined for these trenches.

\subsubsection{Pre-Disposal Treatment Methods}

Waste destined for these trenches will be encapsulated by grout or other cementitious backfill as an alternative to vault disposal. Specific methods and criteria for encapsulation are not yet developed.

\subsubsection{Waste Acceptance Restrictions}

Waste acceptance for disposal in the trenches designated to receive cement-stabilized encapsulated waste must conform to criteria put forth in the SRS WAC.

\subsubsection{Naval Reactor Waste Pads}

Heavily shielded shipping/disposal casks containing NR waste components are planned to be disposed of at the Naval Reactor Pad, within the fenced 100-acre boundary of the E-Area LLWF, at the SRS. Large quantities of activation products are associated with the metal matrix of the waste forms within the disposal containers. Lesser amounts of radioactive contaminants are present in "crud" corrosion products.

\subsubsection{Waste Type/ Chemical and Physical Form}

Within the E-Area LLWF, disposal of up to 100 steel casks with carbon steel or low-alloy steel shipping containers containing NR components is proposed. The NR component waste is composed of activated metals and can include control rods, control rod drive mechanisms, resin vessels, adapter flanges, and similar equipment. The high shielding shipping/disposal containers reduce the safety risks involved in the disposal of NR component wastes. 
Naval Reactor waste consists of a variety of solid activated metal naval nuclear reactor components, including core barrels/thermal shields (CB/TS), adapter flanges, closure heads, holddown (HD) barrels, pumps and other similar equipment. Certain components are also covered with a thin layer of adherent corrosion products, referred to as "crud," which contains lesser amounts of radioactive contamination. These waste components include Bettis CB/TS, HD barrels, Bettis heads, Bettis adapter flanges, Bettis shrouds, Bettis pumps, Knolls Atomic Power Laboratory (KAPL) CB/TS, and KAPL Heads. Volumes of the metal waste components range between 1.05 and $7.05 \mathrm{~m}^{3}$ for each component. Most waste components also contain some water, with the maximum amount being about $9.5 \times 10^{-3} \mathrm{~m}^{3}$ (2.5 gal). More detailed configurational descriptions of the NR waste components are not available because of the classified nature of this information.

\subsubsection{Radionuclide Inventory}

The 20-year projected inventory of radionuclides for 100 naval reactor component waste containers is provided in the PA.

\subsubsection{Waste Volume}

Naval reactor core barrels and reactor components are to be disposed of on gravel pads in the EArea LLWF. The gravel pads have a total storage capacity of 697 square meters $(7,500$ square feet). Up to 100 containers may be disposed at the E-Area LLWF per the PA evaluation. The metal volume of the waste is approximately $3.5 \mathrm{~m}^{3}$ per container.

\subsubsection{Packaging Criteria}

There is no standard Naval Reactor Component waste disposal container due to the variety of waste components. The actual container configuration, thickness, material of construction and closure method may be tailored to the characteristics of the Naval Reactor waste component at the time of disposal. Table 3.3.-1 shows that the planned or proposed containers for Naval Reactor waste disposal are mostly composed of carbon steel or low-alloy steel and closed by a gasket or a weld. The assumed thickness of the container is based on estimated shielding requirements (by Bettis) for a bounding KAPL CB/TS radionuclide inventory. From The overall containerized waste volume is about $43 \mathrm{~m}^{3}$.

The life expectancy and shielding capacity of the shipping/disposal casks are determined by the specifications of the containers.

\subsubsection{Pre-Disposal Treatment Methods}

The offsite generator is responsible for any pre-disposal treatment methods prior to shipment to SRS.

\subsubsection{Waste Acceptance Restrictions}

Waste acceptance for disposal on the Naval Reactor Waste pad must conform to criteria put forth in the SRS WAC. 
Table 3.3-1 Forecast of Naval Reactor Waste Components for E-Area Low-Level Waste Facility Disposal

\begin{tabular}{|c|c|c|c|c|c|c|c|c|c|}
\hline Description & $\begin{array}{c}\text { Bettis } \\
\text { CB/TS }\end{array}$ & $\begin{array}{c}\text { Bettis } \\
\text { H } \\
\text { Barrels }\end{array}$ & $\begin{array}{c}\text { Bettis } \\
\text { Head/CP }\end{array}$ & $\begin{array}{c}\text { Bettis } \\
\text { Head/CP }\end{array}$ & $\begin{array}{l}\text { Bettis } \\
\text { Adapter } \\
\text { Flange }\end{array}$ & $\begin{array}{c}\text { Bettis } \\
\text { Shrouds }\end{array}$ & $\begin{array}{l}\text { Bettis } \\
\text { Pump }\end{array}$ & $\begin{array}{l}\text { KAPL } \\
\text { CB/TS }\end{array}$ & $\begin{array}{c}\text { KAPL } \\
\text { Head }\end{array}$ \\
\hline $\begin{array}{l}\text { Number of } \\
\text { units }^{\prime}\end{array}$ & 8 & 8 & 2 & 10 & 2 & 2 & 1 & 16 & 16 \\
\hline $\begin{array}{l}\text { Gross } \\
\text { Weight (lb) }\end{array}$ & $\begin{array}{r}24100 \\
0\end{array}$ & 159070 & 152600 & 87710 & 26090 & 111350 & 290065 & 360000 & 78000 \\
\hline Component & & & & & & & & & \\
\hline $\begin{array}{l}\text { Component } \\
\text { weight (lb.) }\end{array}$ & 61000 & 59710 & 121920 & 42910 & 18090 & 90130 & 60065 & 72000 & 47000 \\
\hline $\begin{array}{l}\text { Component } \\
\text { volume }\left(\mathrm{ft}^{3}\right)\end{array}$ & 125 & 122 & 249 & 86 & 37 & 184 & 123 & 147 & 96 \\
\hline $\begin{array}{l}\text { Component } \\
\text { Alloy }^{3}\end{array}$ & 304 s.s. & Inconel & $\begin{array}{l}\text { Carbon } \\
\text { steel }\end{array}$ & $\begin{array}{l}\text { Carbon } \\
\text { steel }\end{array}$ & Inconel & $\begin{array}{l}\text { Carbon } \\
\text { steel }\end{array}$ & Inconel & $\begin{array}{l}\text { Inconel/ } \\
\text { Zircaloy }\end{array}$ & $\begin{array}{l}\text { Inconel } \\
\text { clad } \\
\text { c. steel }\end{array}$ \\
\hline $\begin{array}{l}\text { Max water } \\
\text { (gals) } \\
\text { Container }\end{array}$ & 1 & 5 & 13.5 & 0.4 & 1.5 & 8 & 8 & 3.5 & 0 \\
\hline $\begin{array}{l}\text { Container } \\
\text { weight (lb.) }\end{array}$ & 180000 & 99360 & 30680 & 44800 & 8000 & 21220 & 230000 & 288000 & 31000 \\
\hline $\begin{array}{l}\text { Thinnest } \\
\text { thickness of } \\
\text { container } \\
\text { (in) })^{4}\end{array}$ & 5.2 & 4 & 0 & 0 & 0 & 0 & 1.25 & 1.64 & 0 \\
\hline $\begin{array}{l}\text { Container } \\
\text { alloy } \\
\text { Type of } \\
\text { container } \\
\text { closure }\end{array}$ & $\begin{array}{c}\text { Carbon } \\
\text { steel } \\
\text { Full } \\
\text { pen } \\
\text { weld }\end{array}$ & $\begin{array}{l}\text { HY-80 } \\
\text { Full } \\
\text { pen } \\
\text { weld }\end{array}$ & $\begin{array}{l}\text { Carbon } \\
\text { steel } \\
\text { Gasket }\end{array}$ & $\begin{array}{c}\text { Carbon } \\
\text { steel } \\
\text { Gasket }^{2}\end{array}$ & $\begin{array}{c}\text { Carbon } \\
\text { steel } \\
\text { Gasket }\end{array}$ & $\begin{array}{l}\text { Carbon } \\
\text { steel } \\
\text { Gasket }\end{array}$ & $\begin{array}{c}\text { Carbon } \\
\text { steel } \\
\text { Full } \\
\text { pen } \\
\text { weld } \\
\end{array}$ & $\begin{array}{c}\text { Carbon } \\
\text { steel } \\
\text { Full } \\
\text { pen } \\
\text { weld }\end{array}$ & $\begin{array}{c}\text { Carbon } \\
\text { steel } \\
\text { Gasket }\end{array}$ \\
\hline $\begin{array}{l}\text { NOTES: } \\
1 \text { Includes } \\
2 \text { Eight of t } \\
3 \text { Alloy sho } \\
4 \text { Zero indic } \\
\text { SOURCE: } \\
\text { WSRC 2000 }\end{array}$ & $\begin{array}{l}\text { omponents } \\
\text { e Adap. Fla } \\
\text { wn is major } \\
\text { ates gaskete }\end{array}$ & $\begin{array}{l}\text { ecently shi } \\
\text { nge contai } \\
\text { alloy of co } \\
d \text { and bolte }\end{array}$ & $\begin{array}{l}\text { ipped and ide } \\
\text { ners were we } \\
\text { istruction. } \\
\text { ed closure. }\end{array}$ & $\begin{array}{l}\text { fied as ab } \\
\text { d shut. T }\end{array}$ & $\begin{array}{l}\text { ground } \\
\text { mainin }\end{array}$ & $\begin{array}{l}\text { B/TS } \\
\text { o will }\end{array}$ & ber ga & $\begin{array}{l}8 \text { Ada } \\
\text { ed and }\end{array}$ & $\begin{array}{l}\text { Flanges) } \\
\text { lted. }\end{array}$ \\
\hline
\end{tabular}




\subsection{TECHNICAL APPROACH TO CLOSURE}

One of the key objectives of any closure of a waste disposal site is to limit moisture flux through the waste, thus minimizing contamination of the underlying groundwater. Because the E-Area LLWF is designed as a controlled release facility, proper closure to meet the objective of limiting moisture through the waste will be an integral part of long-term acceptability of the disposal site. Because backfilling and final closure of the E-Area LLWF will be delayed for several years, a detailed closure design has not been fully developed for the E-Area LLWF. Thus an integral part of the E-Area LLWF PA required that a closure concept be described and subsequently tested in models that simulate the performance characteristics of the proposed closure concept. Certain details of the closure concept are discussed in Sections 3.2 and 3.3.

\subsection{Compliance with Performance Objectives and Other Requirements}

Each disposal unit at the E-Area LLWF has been designed, is operated and will be closed in accordance with the Performance Objectives set forth in USDOE Order 435.1 (USDOE 1999). Closure activities are thus an important part of the overall waste management system at SRS.

\subsubsection{All Pathways Dose}

As shown in the PA (WSRC 2000), the calculated dose from the All Pathways scenario is totally due to contaminant transport by the groundwater pathway. Therefore, the primary parts of the closure system that are significant to the All Pathways performance objective are the hydraulic properties of the cover system. These are the porosity, saturated hydraulic conductivity and relative hydraulic conductivity of the barrier, and drainage and fill layers of the cover system. Other factors that will be considered during closure design include:

- the amount of cap overhang

- the durability of the system

- the configuration of the system

- the size of the drains

- the thickness of each layer

- filter design

- design features to withstand subsidence

- design features for erosion control.

\subsection{2 $\quad$ Air Pathway Dose}

The only feature of the closure system that is a factor in the calculation of the air pathway dose is the total thickness of the cover system.

\section{$\underline{\text { 4.1.3 }} \quad \underline{\text { Radon Flux }}$}

The major feature of the closure system that is a factor in the calculation of the radon flux is the total thickness of the cover system. 


\subsubsection{Other Requirements}

\subsubsection{Groundwater Resource Protection}

The closure system features that are significant to the Groundwater Resource Protection requirement are the hydraulic properties of the cover system. These are the porosity, saturated hydraulic conductivity and relative hydraulic conductivity of the barrier and drainage and fill layers of the cover system.

\subsubsection{Intruder Protection}

The important parameter in the closure systern for Intruder Protection is the total thickness of the cover system. This thickness provides shielding from gamma radiation and dilution of the waste in scenarios involving excavation.

\subsection{Detailed Closure Activities}

When each disposal unit is filled, interim closure activities will be performed. When the entire EArea LLWF is filled, the entire site will undergo final closure. The final closure will thus be the same for each disposal unit.

\subsubsection{Operational/Interim Closure}

\subsubsection{Trench Disposal Units}

As each trench unit is filled, a cover consisting of 4 feet of clean soil will be placed on top of the waste. The cover will provide shielding for operations personnel and bring the trench excavation back to original grade. An interim vegetative cover of shallow rooted grass will be established to help control erosion.

\subsubsection{Low-Activity Waste Vault Units}

After individual cells are filled with waste, all of the external wall openings (i.e., large exterior door, small interior door and exhaust fan openings) will be formed and filled with reinforced concrete to provide continuous, structurally sound walls to isolate the waste from the environment.

\subsubsection{Intermediate-Level Vault Units}

After the final layer of waste containers is placed in a cell, a final layer of grout will be placed in the cell and will be leveled at the wall ledges used to support the shielding slabs. A permanent roof slab of reinforced concrete will then be placed over the nine $\mathrm{IL}$ Vault cells. The slab will then be covered with fiberboard and a layer of waterproof membrane roofing.

\subsubsection{Final Closure}

\subsubsection{Cover System Design and Design Objectives}

The E-Area LLWF cover system will be a multi-layer, low-permeability cover system. A conceptual cross sectional view of initial cover system design is depicted provided in the PA. 
The design objectives of the E-Area LLWF Closure are to:

- minimize stormwater infiltration with minimum maintenance

- accommodate settling and subsidence of fill material to maintain cover integrity with ease of maintenance

- minimize erosion and abrasion of the final cover

- maintain a permeability or hydraulic conductivity less than or equal to $10^{-7} \mathrm{~cm} / \mathrm{sec}$.

\subsubsection{Cover System Performance}

The E-Area LLWF will be closed in a manner that minimizes the need for further maintenance and controls the release of waste constituents consistent with the performance objectives. To this end, the final cover will be designed and constructed to:

- provide long term minimization of migration of liquids through the waste

- function with minimum maintenance

- promote drainage and minimize erosion or abrasion of the cover

- accommodate settling and subsidence so that the cover's integrity is maintained.

Seismic conditions were reviewed and it was determined that no active faults are located within the proximity of the E-Area LLWF and earthen fill embankments. Underlying subsoil and embankment side slope deformation is negligible and liquefaction potential is also negligible for general site (SRS) facilities.

The general cover system proposed in this closure plan was developed and installed as part of the F- and H-Area Seepage Basin Closures at SRS. This cover system employs natural materials characteristics favorable for long-term performance and demonstrates the feasibility of this type of system.

\subsubsection{Subgrade Preparation}

The subgrade portions of the E-Area LLWF closure will be compacted to provide a foundation structure upon which the final closure cover system structure will be placed. The compaction activities will be followed by placement of backfill to meet final design grades. The following sections describe the subgrade.

\section{Compression of Trench Subsoil}

As determined in Volume I of the Mixed Waste Management Facility (MWMF) Closure Plan (WSRC 1999a), settlement of the final cover can result from compression of the trench subgrade due to the overlying weight of the landfill waste, initial backfill, and cover system. This settlement can be estimated using geotechnical engineering design methods based on several components, including elastic compression, which occurs as load is applied; primary consolidation, which occurs over a period of time as water is expelled from the soil voids in the 
foundation soil; and secondary consolidation/creep, which occurs slowly over a long period of time in certain soils.

Based on the information in Volume I of the MWMF Closure Plan, settlement of trench subsoil at the E-Area LLWF will be minor.

\section{Subsidence of Waste}

Some subsidence may occur during the 100-year institutional control period. Inspection and maintenance programs will be implemented to address these occurrences.

The B-25 boxes, which are buried within the trenches, are subject to long-term deterioration as a result of oxidation of the metal. Because of the lack of information on the void space within the boxes, exact compression potentials are difficult to determine. The amount of void space within the B-25 boxes relates directly to long-term subsidence associated with the weight of the backfill and the cover system material on top of the boxes.

\section{Preparation of Existing Grade}

The closure areas will be rough graded to establish a base elevation for the cover system. Each closure area will then be consolidated with a vibratory roller prior to the placement of backfill.

The detailed design documents, when developed, will require the contractor to use care in the exposure of the clay and to minimize vehicular traffic on the existing cap to preclude damage to the existing cover. Additionally, the removal of the vegetative layer will be limited to minimize weathering of the exposed kaolin clay. The contractor will be required to avoid sudden stops, starts, or turns of construction equipment directly on the exposed kaolin clay layer to protect it.

\subsubsection{Cover System}

The cover system material will consist of layers that will be placed from bottom to top. All materials and their placement will meet the design requirements, which will also include provisions for protection of the integrity of the E-Area LLWF clay cap.

The cover system configurations are shown in Appendix A. Each specific area has its own individual configuration. However, each area's cover will use the same cover system features, as follows:

- final grade of three to five percent slope

- multi layer system (i.e., foundation layer, clay liner, drainage layer, vegetation/soil layer)

- minimal impact on area operations and infrastructure.

\section{Backfill Layer}

The backfill layer material will be placed in a manner that prevents or minimizes possible contamination. This material will consist of a compacted fill material to support the cover system. The backfill layer material will be obtained from on-site sources in accordance with the project requirements. 
Prior to the placement of the backfill layer, the existing soil cover over the waste areas will be stabilized by vibratory rolling. Once stabilized, the backfill layer material will be placed in horizontal layers not to exceed 9 inches in uncompacted thickness in areas where hand-operated mechanical equipment is used and not to exceed 12 inches in uncompacted thickness in areas where self-propelled or towed mechanical equipment is used. Each horizontal layer will be compacted to at least 90\% Modified Proctor Density Test (ASTM D1557 [ASTM 1992a]) or 95\% Standard Proctor Density Test (ASTM D698 [ASTM 1992]) of the maximum dry density within specified tolerances of the optimum moisture content, before the next lift is placed. The backfill material will conform to specified gradation requirements as determined by ASTM D422 (ASTM 1992b).

Future revisions of the closure plan will describe the recommended tests that will be performed to assure compliance with closure requirements and the project specification.

An Independent Professional Engineer will be retained by SRS to certify that the E-Area LLWF, as shown on the drawings provided in Appendix A, has been closed in accordance with this approved closure plan.

The backfill layer provides structural support for the cap and is not intended to contribute to the hydraulic conductivity requirements.

The thickness of the backfill layer varies, and acts as a leveling course, matching uneven existing terrain with a smooth-graded closure cap. The nominal thickness of the compacted backfill layer will vary from a 2 -foot minimum to approximately 7 feet.

A total of 2 feet of soil above the backfill layer will result in approximately 300 pounds per square foot (PSF) of load, onto the backfill layer. The bearing capacity of the compacted backfill layer soil is in the order of magnitude of 2,000 PSF. This provides an acceptable degree of confidence that the backfill layer will support the cap loads.

\section{Clay Liner}

The clay liner will conform to the final grade and meet project requirements for installation and anchoring. The purpose of this layer is to impede infiltration.

The E-Area LLWF closure cover system uses a compacted clay layer to form the lower component of the low-hydraulic conductivity barrier. Historically at SRS, a compacted clay layer has been used as the hydraulic barrier with a thickness of 24 inches and verified hydraulic conductivity of $1 \times 10^{-7} \mathrm{~cm} / \mathrm{sec}$ (MRCE 1988).

\section{Gravel Layer}

The gravel layer will provide effective transport of water from the vegetative layer and will resist erosion. Water that infiltrates through the top vegetative layer will be drained by gravity from the cover system by the gravel layer.

The gravel layer will consist of a one-foot thick gravel layer with a hydraulic conductivity of at least of $1 \times 10^{-3} \mathrm{~cm} / \mathrm{sec}$. 


\section{Vegetation / Topsoil Layer}

The final cover layer will consist of soils capable of supporting a vegetative cover. The final cover will be free from substances that prevent satisfactory compaction and/or pose a potential to damage the uppermost surface of the underlying cover. The final cover will be placed in compacted lifts. Geotextile filter material may be placed between cover system layers to impede mixing of materials over time.

\section{$\underline{\text { Vegetation }}$}

The surface of the final cover layer will be fertilized, seeded, and mulched to provide a vegetative cover. The final cover crop will be a persistent, shallow rooted species, such as bamboo, that will effectively minimize erosion and sustain growth with minimal maintenance.

An initial crop of a persistent grass may precede planting of the final vegetative material. During seeding and establishment of the initial crop, appropriate mulch, erosion control fabric, or similar substances will protect the surface. The area will be repaired through transplanting or replanting to ensure that a permanent self-maintaining cover is developed.

\subsubsection{Surface Drainage and Erosion Control}

\section{Drainage Design Concept}

The drainage- design will:

- minimize run-on from adjacent areas

- minimize the development of rills, gullies, or sheet erosion on the cover systems

- meet site drainage requirements without inducing localized flooding

- minimize infiltration of stormwater runoff into the waste disposal areas.

The drainage system will be improved prior to cover system placement. The system will tie into existing stormwater conveyance systems to the extent practical. The drainage systems may use the existing E-Area LLWF conveyance system. Sloped cover areas will divert runoff away from all closure areas.

\section{Erosion Control}

Erosion control will prevent erosion along all portions of the E-Area LLWF closure areas. Topsoil preparation and vegetation will reduce the potential for soil erosion.

Criteria used in the design of the cover system to reduce erosion include the following:

- minimize top surface slopes to between 3 to 5 percent, where feasible

- minimize side slope grades wherever possible

- establish a cover crop as quickly as possible. 


\section{Stormwater Management and Sediment Control}

The E-Area LLWF drainage design will provide for the conveyance of stormwater runoff from all designated closure areas.

All channels and culverts will be designed to convey non-erosive flow in order to minimize erosion potential. Closure cover system surface slopes will also be designed to minimize erosion potential.

In areas of potential erosion, erosion and sediment control measures will be used in an effort to protect surface soils from erosion and to retain migrating soils on site.

\section{$\underline{4.2 .3} \quad \underline{\text { Institutional Control }}$}

USDOE has committed to a term of institutional control of not less than 100 years following final closure of the E-Area LLWF. During this time periodic inspections will be conducted and maintenance activities will be performed as needed.

\subsubsection{Unrestricted Release of Site}

The current SRS Future Use Plan states that the entire Savannah River Site will never be released for unrestricted use. In particular, the plan states that the central portion of the SRS, which includes the E-Area LLWF, will only be used for industrial purposes (USDOE 1998). This is consistent with the PA assumption of 100 years of restricted use for the intruder scenario. Following the 100-year timeframe, the PA assumes total failure of the units.

\subsection{Monitoring}

\subsubsection{Operational/Interim Closure}

During the operational and interim closure periods, the E-Area LLWF will have a monitoring program in place. The program will include a vadose zone monitoring system around and underneath trench disposal units, scheduled sampling and analysis of any water found in vault disposal unit sumps, and visual inspection of all disposal units as discussed in the E-Area Monitoring Program for the E-Area Low-Level Radioactive Waste Facility (WSRC 2000a). Additional details of the monitoring system will be included as the monitoring plan develops.

\subsubsection{Final Closure/Institutional Care}

Following final closure and during the institutional control period, the E-Area LLWF will be part of the overall SRS Environmental Monitoring Program. Groundwater samples will be taken on a regularly scheduled basis. The samples will be analyzed for constituents that could indicate release of contaminants from the E-Area LLWF.

Periodic inspections of the closure system will be performed. Maintenance activities necessary for continued system performance will be conducted as required.

\subsection{CLOSURE SCHEDULE}

As discussed previously, the E-Area LLWF is in the very early stages of its planned operational life. This closure plan reflects the currently available information based on the facility's 
operational status. As operations continue, the closure plan will be updated to reflect the most current operational features that must be considered during closure. The schedule for final closure of the facility will be developed five years prior to completion of waste emplacement activities.

\subsection{REFERENCES}

Aadland et al. 1995. Hydrogeologic Framework of West-Central South Carolina. Aadland, R.K., Gellici, J.A., and Thayer, P.A. South Carolina Department of Natural Resources, Water Resources Division, Report 5, Columbia, South Carolina. 1995.

ASTM 1992. Standard Test Method for Laboratory Compaction Characteristics of Soil Using Standard Effort $\left(12,400 \mathrm{ft}-1 \mathrm{bf} / \mathrm{ft}^{3}\left(600 \mathrm{kN} \mathrm{m}^{*} / \mathrm{m}^{3}\right)\right)$. American Society of Testing and Materials (ASTM), Annual Book of ASTM Standards, Volume 04.08, Soil and Rock; Dimension Stone; Geosynthetics, ASTM D-698-91. American Society of Testing and Materials, Philadelphia, PA. 1992

ASTM 1992a. Standard Test Methods for Moisture-Density Relations of Soil and Soil-Aggregate Mixtures Using 10-lb. (4.54-kg) Rammer and 18-in. (457- $\mathrm{mm})$ Drop, American Society of Testing and Materials (ASTM), Annual Book of ASTM Standards, Volume 04.08, Soil and Rock; Dimension Stone; Geosynthetics, ASTM D-1557-91. American Society of Testing and Materials, Philadelphia, PA. 1992

ASTM 1992b. Standard Test Method for Particle-Size Analysis of Soils, American Society of Testing and Materials (ASTM), Annual Book of ASTM Standards, Volume 04.08, Soil and Rock; Dimension Stone; Geosynthetics, ASTM D-422-(90)e1. American Society of Testing and Materials, Philadelphia, PA. 1992

MRCE 1988. Clay Cap Test Evaluation Report, Mixed Waste Management Facility Closure. Mueser Rutledge Consulting Engineers. 1988.

USDOE 1998. Savannah River Site Future Use Plan. United States Department of Energy, Aiken, South Carolina. March 1998.

USDOE 1999. Radioactive Waste Management. Office of Environmental Management, DOE 435.1. United States Department of Energy, Washington, DC. July 9, 1999.

USDOE 1999a. Radioactive Waste Management Manual. Office of Environmental Management, DOE M 435.1-1. United States Department of Energy, Washington, DC. July 9, 1999.

USDOE 1999b. Disposal Authorization Statement for the Department of Energy Savannah River Site E-Area Vaults and Saltstone Disposal Facilities. United States Department of Energy, Washington, DC. September 28, 1999.

USDOE 1999c. Format and Content Guide for U.S. Department of Energy Low-Level Waste Facility Closure Plans. United States Department of Energy, Washington, DC. November 10, 1999.

WSRC 1999. Savannah River Site Waste Acceptance Criteria Manual IS, Low-Level Waste Acceptance Criteria Procedure 3.17, Rev. 2. Westinghouse Savannah River Company, Aiken, South Carolina. June 10, 1999. 
WSRC 1999a. Mixed Waste Management Facility Closure Plan (LLRWDF), Volume II (u), Rev 4. (Q-CLP-E-00001). Westinghouse Savannah River Company, Aiken, South Carolina. September 1999.

WSRC 2000. Radiological Performance Assessment for the E-Area Low-Level Waste Facility, Rev. 1 (WSRC-RP-94-218). Westinghouse Savannah River Company, Aiken, South Carolina. January $31,2000$.

WSRC 2000a. E-Area Monitoring Program for the E-Area Low-Level Radioactive Waste Facility, Rev. 11 (SWD-SWE-0153). Westinghouse Savannah River Company, Aiken, South Carolina. March 2000.

WSRC 2000b. Maintenance Program for the E-Area Low-Level Waste Facility and Saltstone Performance Assessments and the Composite Analysis, (SWD-SWE-2000-00053). Westinghouse Savannah River Company, Aiken, South Carolina. April 6, 2000. 
THIS PAGE INTENTIONALLY LEFT BLANK

Rev. 1 
Appendix A

Initial Closure Design

Rev. 1 
This appendix contains conceptual construction drawings for the E-Area LLWF. The drawings provide sufficient information for planning purposes and evaluation of the constructibility of the conceptual closure system described in the PA, but they are not intended to be design drawings. Based upon the initial conceptual design, it appears that there is sufficient area to construct the disposal facilities and the closure system. Some fairly substantial grading will be required.

The drawings were developed by overlaying current site topography with presently planned disposal areas in E-Area. Figure A! shows the disposal units overlaying the current topography. There are four types of waste disposal units shown on the drawing; they are LAW Vaults, lowactivity waste trenches, IL vaults, and the NR Pads. These waste units are described in detail in the body of this report. There are twenty-one LAW units, ten IL vaults, and eight NR Pads. The LAW units are either a LAW vault or five trenches that comprise the same area as a LAW Vault. For this conceptual design, underneath the first capped area it is assumed that there will be four LAW vaults and seven groups of five trenches. The final configuration of trenches and LAW vaults will $b$ determined by waste disposal needs. This leaves ten additional LAW units that could be constructed.

Figures A2, A3 and A4 provide sample cross-sections through the LAW vaults, ILW vaults, and NR Pads, respectively. The locations of the cross-sections are shown on Figure A1 and A-A', BB' $^{\prime}$ and C-C'. For the IL and LAW units, the surface construction grade is approximately 280 feet above msl. The construction grade for the NR Pads is 276 feet above msl. Given the preconstruction topography, grading of the surface is required to construct the vaults, trenches and pads in E Area. The final topography is shown in Figure A5. The final topography shown is based upon grading, vault construction information, and a low-permeability cover.

As described in the report, the units are covered with a low-permeability cover that is intended to drain water away from the units. The cover consists of approximately three feet of backfill, 2.5 feet of clay, one foot of gravel for drainage, $1 / 2$ foot of sand to provide a base for the geotextile fabric, an additional 2.5 feet of backfill and $1 / 2$ foot of topsoil. Vegetation will be planted for erosion control and will also help to transpire water. The slope on the sides of the cap is a rise to run of 1:3, or about 18.4 degrees. The water that is diverted by the clay layer will be collected in a drainage system along the edges of the cap. After the covers are completed, the top surface elevation for the LAW and IL cap areas is 290 feet grading to the side at 280 feet. The NR waste is placed on grade at 276 feet and the waste material and the cover rises to 296 feet above msl. The sides of the NR cover grade to 276 feet to a drainage collection system. The LAW and IL Vault areas are completed with two separate covers and the NR waste is covered with a single cap. This reduces the time that the vaults are left uncovered. 


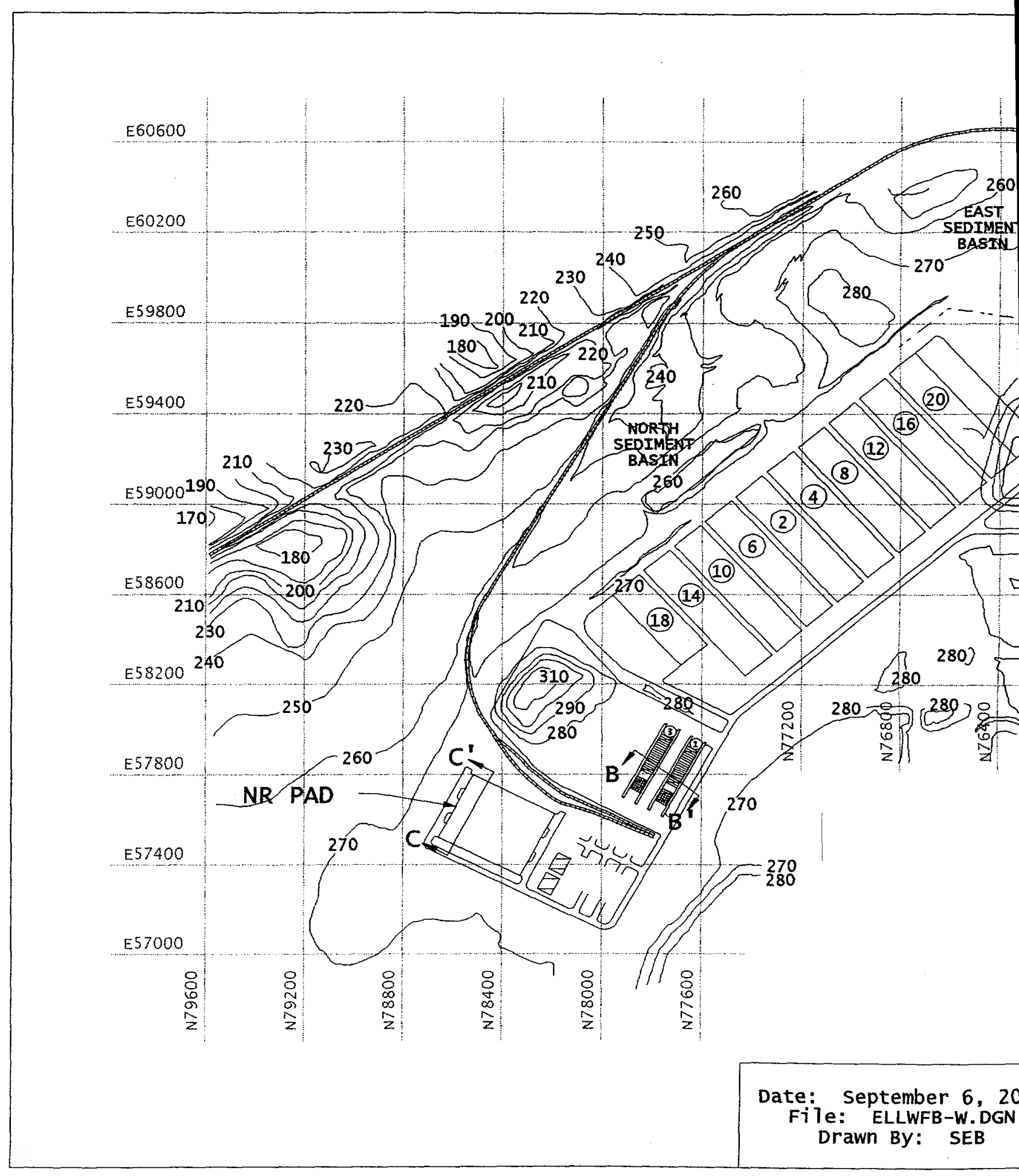




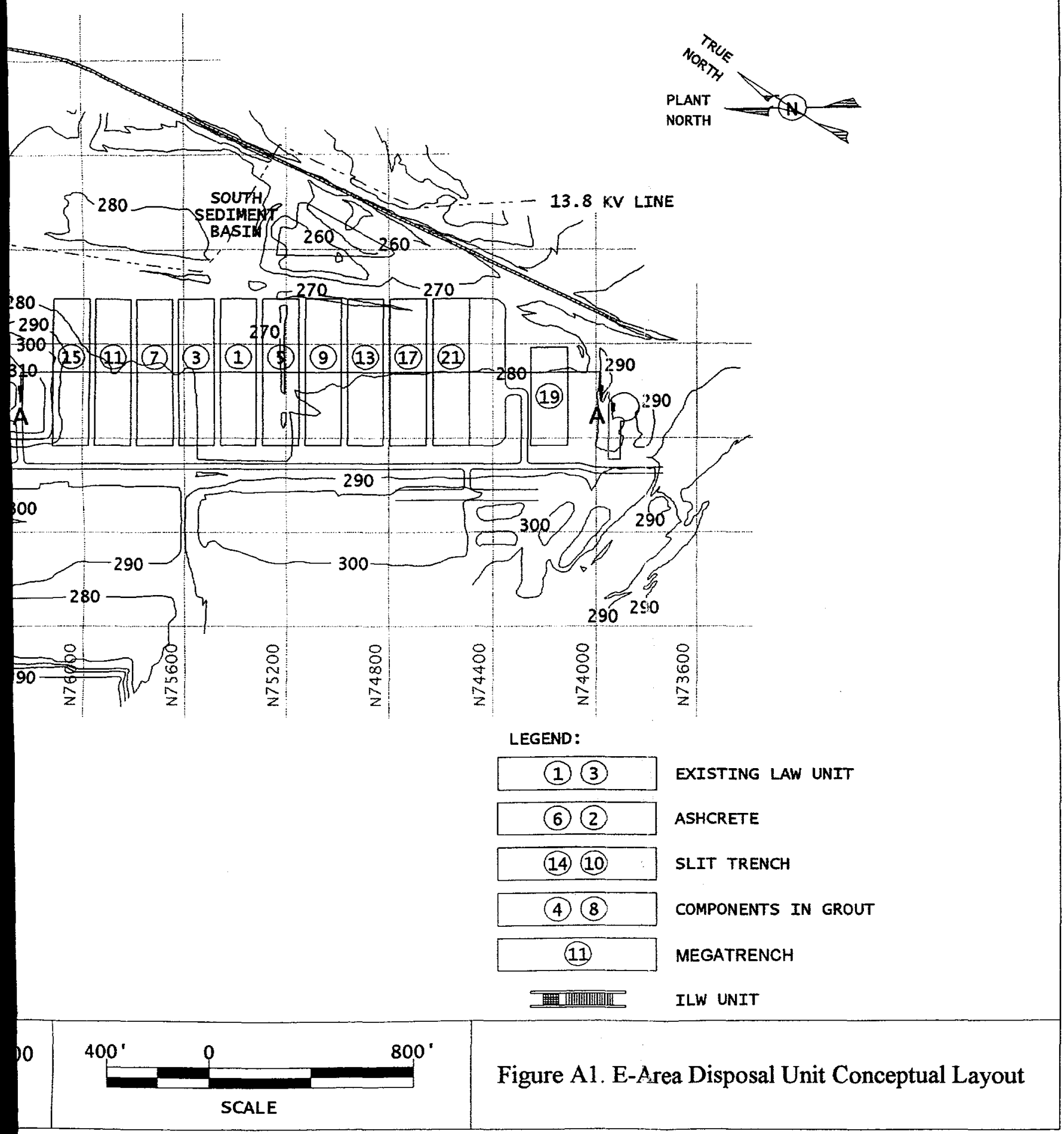




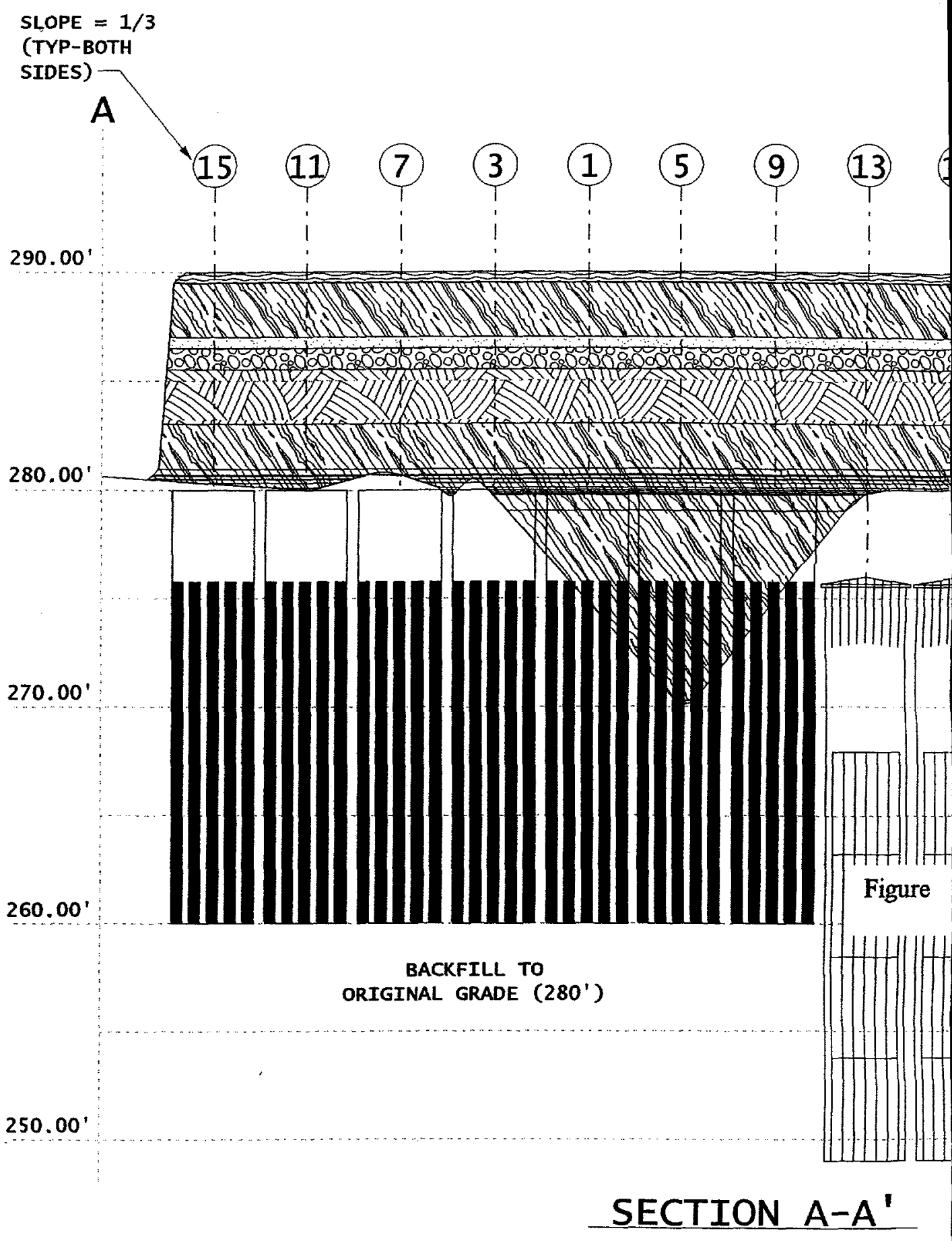




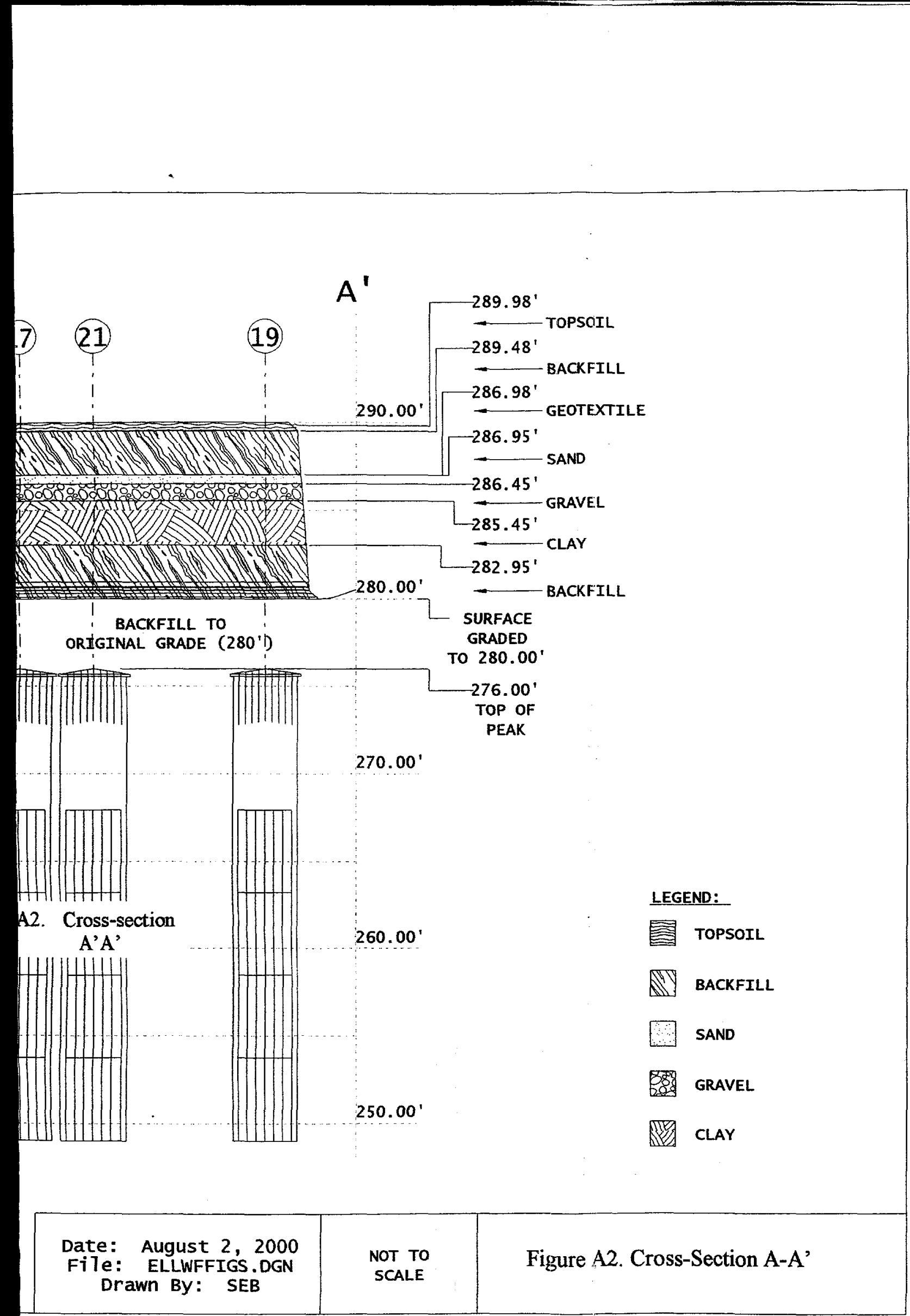




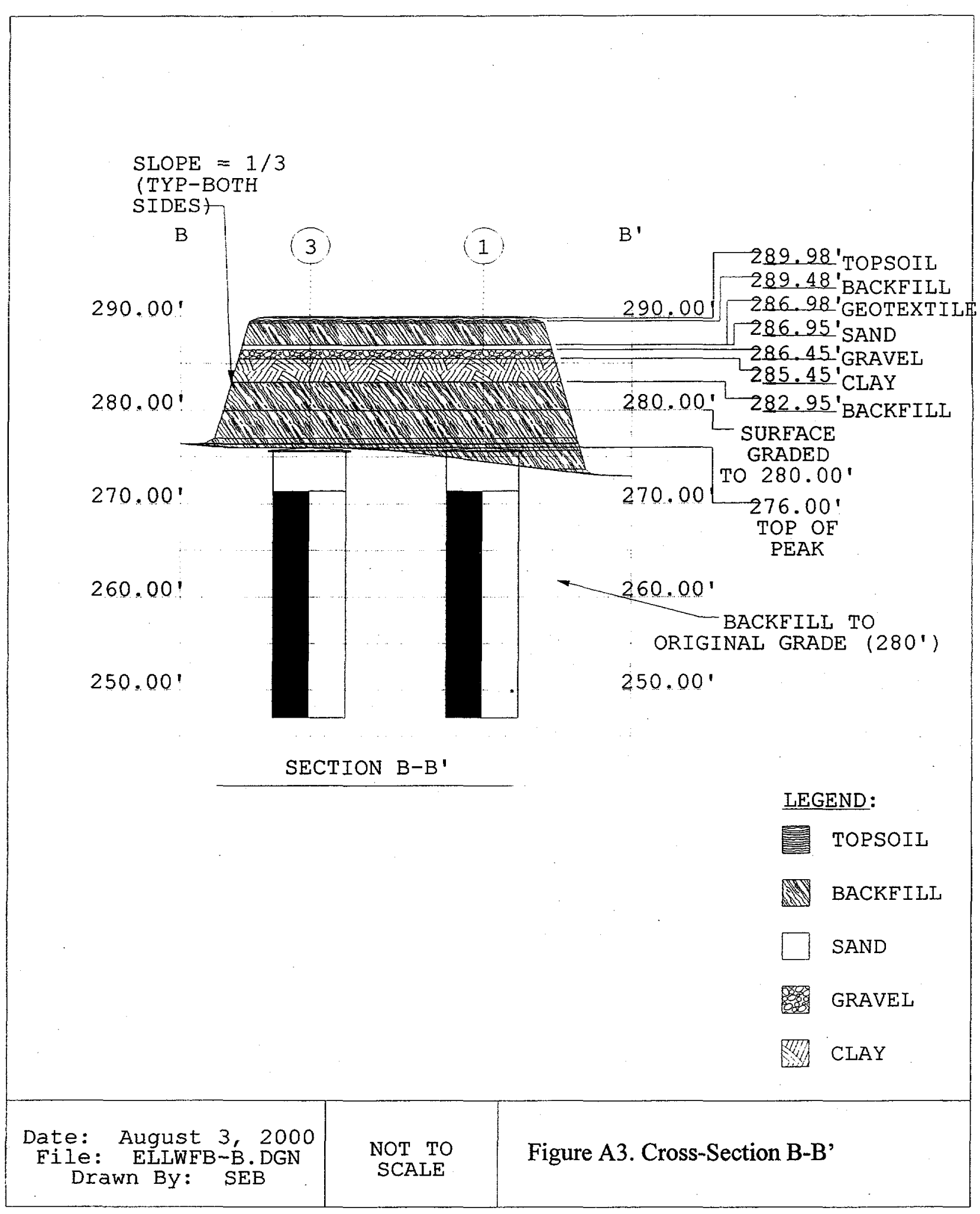




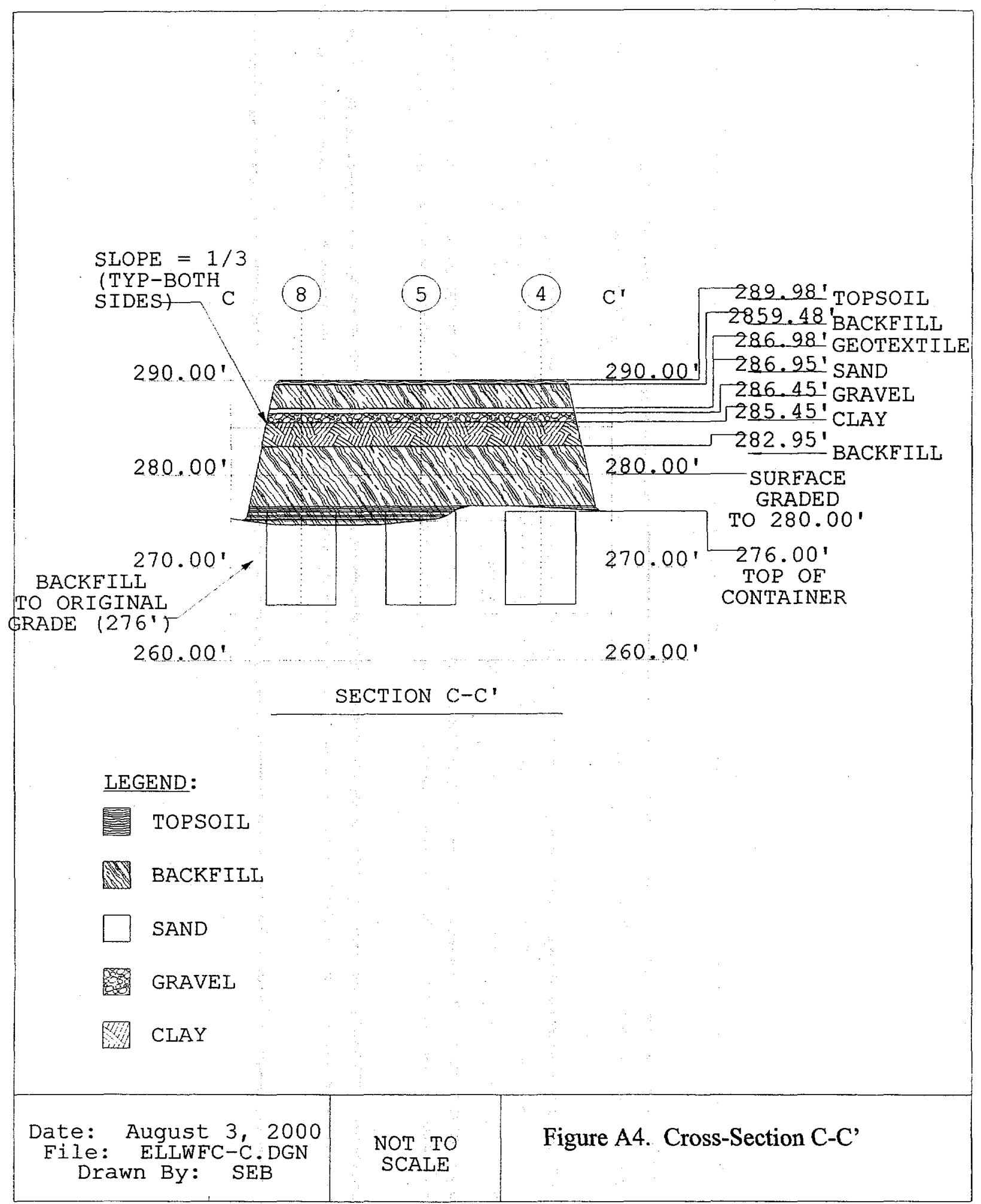




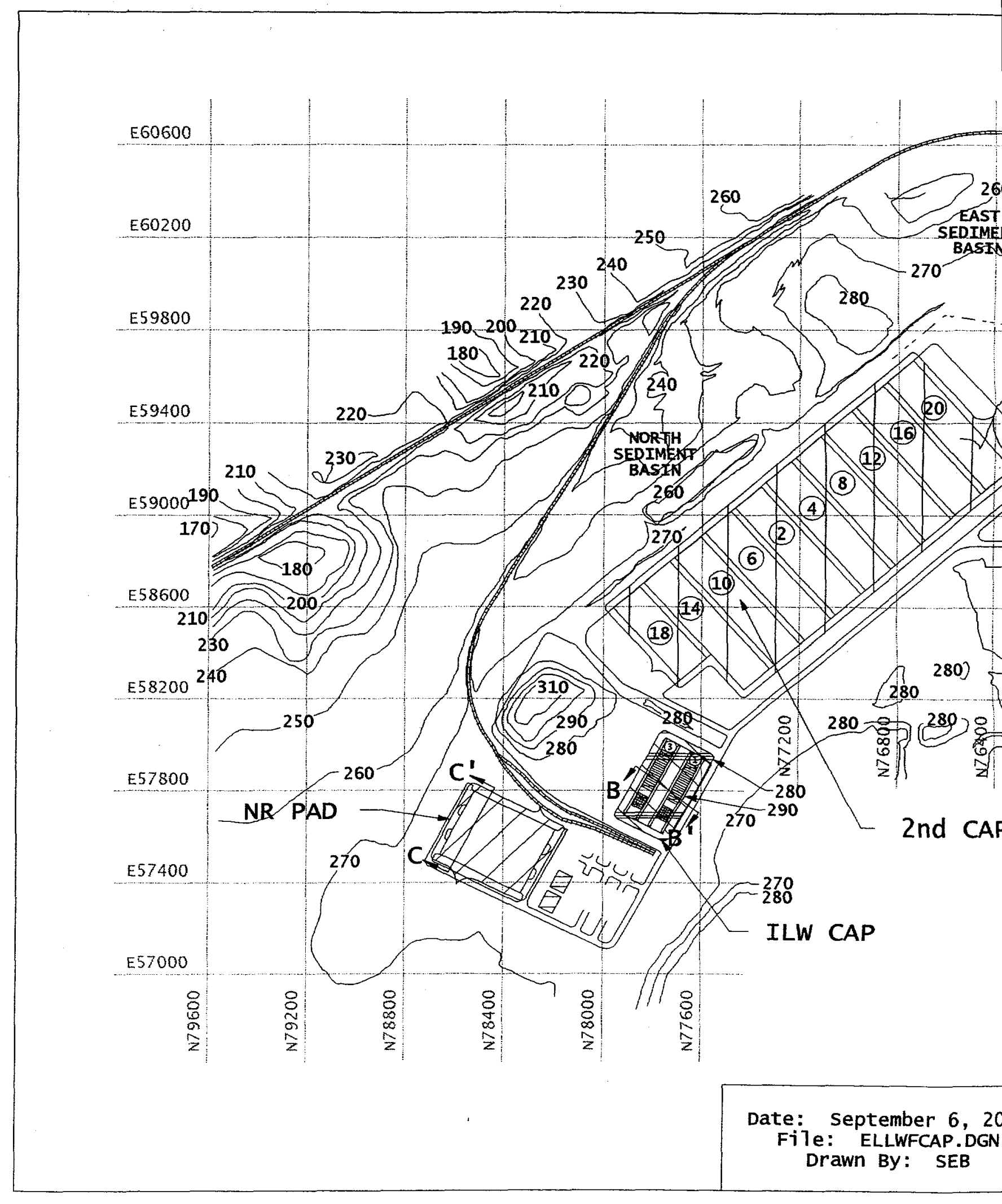


